\title{
No island-effect on glucocorticoid levels for a rodent from a near-shore archipelago
}

\author{
Nathan D Stewart ${ }^{1}$, Gabriela F Mastromonaco ${ }^{2}$, Gary Burness ${ }^{\text {Corresp. } 3}$ \\ 1 Environmental and Life Sciences Graduate Program, Trent University, Peterborough, Ontario, Canada \\ 2 Reproductive Physiology, Toronto Zoo, Toronto, Ontario, Canada \\ 3 Department of Biology, Trent University, Peterborough, Ontario, Canada \\ Corresponding Author: Gary Burness \\ Email address: garyburness@trentu.ca
}

Island rodents are often larger and live at higher population densities than their mainland counterparts, characteristics that have been referred to as "island syndrome". Island syndrome has been well studied, but few studies have tested for island-mainland differences in stress physiology. We evaluated island syndrome within the context of stress physiology of white-footed mice (Peromyscus leucopus) captured from 11 islands and 5 mainland sites in Thousand Islands National Park, Ontario, Canada. Stress physiology was evaluated by quantifying corticosterone (a stress biomarker), the primary glucocorticoid in mice, from hair and its related metabolites from fecal samples. White-footed mice captured in this near-shore archipelago did not display characteristics of island syndrome, nor differences in levels of hair corticosterone or fecal corticosterone metabolites compared with mainland mice. We suggest that island white-footed mice experience similar degrees of stress in the Thousand Islands compared with the mainland. Although we did not find evidence of island syndrome or differences in glucocorticoid levels, we identified relationships between internal (sex, body mass) and external (season) factors and our hormonal indices of stress in white-footed mice. 
1 No island-effect on glucocorticoid levels for a rodent

2 from a near-shore archipelago

3

4

5

6

7

8

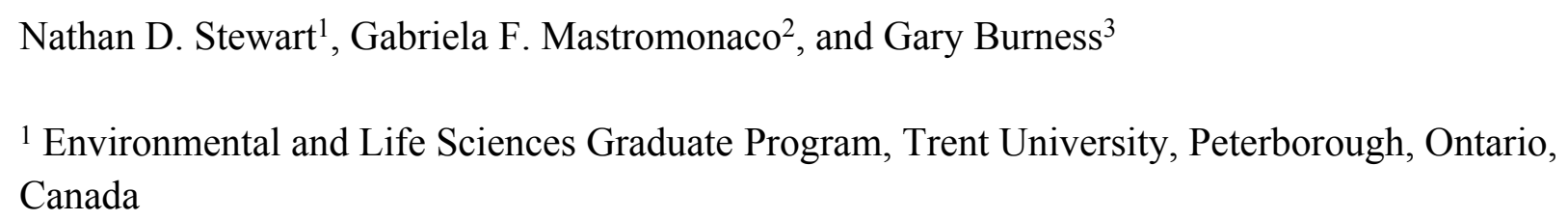

\section{ABSTRACT}

Island rodents are often larger and live at higher population densities than their mainland counterparts, characteristics that have been referred to as "island syndrome". Island syndrome has been well studied, but few studies have tested for island-mainland differences in stress physiology. We evaluated island syndrome within the context of stress physiology of whitefooted mice (Peromyscus leucopus) captured from 11 islands and 5 mainland sites in Thousand Islands National Park, Ontario, Canada. Stress physiology was evaluated by quantifying corticosterone (a stress biomarker), the primary glucocorticoid in mice, from hair and its related metabolites from fecal samples. White-footed mice captured in this near-shore archipelago did not display characteristics of island syndrome, nor differences in levels of hair corticosterone or fecal corticosterone metabolites compared with mainland mice. We suggest that island whitefooted mice experience similar degrees of stress in the Thousand Islands compared with the mainland. Although we did not find evidence of island syndrome or differences in glucocorticoid levels, we identified relationships between internal (sex, body mass) and external (season) factors and our hormonal indices of stress in white-footed mice.

\section{INTRODUCTION}

Studying island ecosystems and species has been central to the development of ecological and evolutionary theory (Foster, 1964; MacArthur \& Wilson, 1967; Van Valen, 1973; Lomolino et al., 2012; Warren et al., 2015). Island communities tend to have low species diversity compared with mainland systems (Losos \& Ricklefs, 2009), including fewer native predators (Blackburn et al., 2004). In response to decreased predator pressure and interspecific competition, combined 
with changes in food availability on islands, small mammals evolve towards gigantism upon arrival to islands while larger species often display dwarfing (Lomolino et al., 2012). This pattern, observed across numerous archipelagos, contributes to the evolutionary trend called the "island rule" (Van Valen, 1973). Behavioural and morphological changes co-occur in small mammals following island colonization, with individuals becoming less aggressive to conspecifics and demonstrating less predator avoidance behaviour (Adler \& Levins, 1994). The combination of increased body size with changes in behaviour and demography has been referred to as "island syndrome" in rodents (Adler \& Levins, 1994). Although morphological and behavioural traits associated with island syndrome have been relatively well-characterized, few studies have focused on the effect of island life on stress physiology (but see (Clinchy et al., 2004; Müller et al., 2007).

When an animal encounters a perceived stressor, its hypothalamic-pituitary-adrenal (HPA) axis is activated, resulting in increased secretion of glucocorticoid hormones (GCs; Sapolsky, Romero \& Munck, 2000). Multiple environmental factors can influence GC levels, including predation (Clinchy et al., 2011; Sheriff, Krebs \& Boonstra, 2011), food availability (Kitaysky, Wingfield \& Piatt, 1999; Walker, Wingfield \& Boersma, 2005) and population density (Boonstra \& Boag, 1992; Harper \& Austad, 2004; Dettmer et al., 2014; Blondel et al., 2016). Elevated GC levels are involved in preparation for future stressors by shifting resources from reproduction and digestion toward replenishing energy stores used during the initial stress response (Romero \& Wingfield, 2016). Although short-term elevations of GCs are presumed to be adaptive, chronically elevated GCs may correlate negatively with indices of wildlife health (Stothart et al., 2016), condition (Injaian et al., 2019), and survival (Wilkening and Ray, 2016).

In wildlife studies, stress has traditionally been evaluated by quantifying circulating GC levels from blood samples (Sapolsky, 1982; Wingfield, Smith \& Farner, 1982). However, there is increasing interest in quantifying GCs from less-invasive alternative sources, including saliva, feces and hair (Sheriff et al., 2011). Importantly, comparing measures of GC levels in different materials allows for stress to be evaluated over different time scales (Sheriff et al., 2011). For example, wild eastern chipmunks (Tamias striatus) from more open environments had higher fecal cortisol metabolites than those from more forested areas; however, there was no difference in long term stress between the two groups based on hair cortisol (Mastromonaco et al., 2014). Although concerns have been raised regarding interpretation of both fecal (Goymann, 2012) and hair GCs (Sharpley, Kauter \& McFarlane, 2009; Keckeis et al., 2012; Stewart et al., 2018), a meta-analysis suggests they are useful metrics for quantifying an individual's response to environmental stressors (Dantzer et al., 2014).

Hair GC levels are influenced by both internal and external factors (Romero \& Wingfield, 2016; Heimbürge, Kanitz \& Otten, 2019). Hair GC levels vary within individuals between body regions (Macbeth et al., 2010; Acker, Mastromonaco \& Schulte-Hostedde, 2018) 
and among individuals by age (Dettmer et al., 2014), body size (Waterhouse et al., 2017), condition (Cattet et al., 2014), sex (Stewart et al., 2018), food availability (Cattet et al., 2014) and season (Martin \& Réale, 2008). Further, a study of captive rhesus macaques showed that hair GC levels increased with population density (Dettmer et al., 2014). Fecal GC levels are also influenced by internal and external factors in wild mammals (Hayssen, Harper \& DeFina, 2002; Smith et al., 2012; Mastromonaco et al., 2014).

Animals display a range of physiological adaptations to island life. For example, immunological differences exist between bluebirds (Sialia sialis) from Bermuda and the continental United States (Matson et al., 2014). Caviomorph rodents from small islands have lower basal metabolic rates than their mainland counterparts (Arens \& McNab 2001). With respect to stress physiology, circulating corticosterone levels were lower in blue tits (Parus caeruleus) from the island of Corsica than mainland France (Müller et al., 2007). Although some data are available for changes in glucocorticoid levels in response to island life for birds, demonstration of a pattern similar to the island rule or island syndrome is lacking. The ecological factors shown to affect GC levels in wildlife (e.g., predation, competition, and resource availability) are also thought to account for island syndrome in rodents (see Adler \& Levins, 1994). Given that island syndrome is largely attributed to decreased predation pressure experienced by island rodents (Adler \& Levins, 1994), and that low predation is associated with low GC levels (Clinchy et al., 2011), we predicted that populations of island rodents displaying island syndrome would also have lower GC levels than their mainland relatives.

Although many island-mainland comparisons of behavioural and physiological characteristics have been made using wildlife from isolated oceanic islands (Müller et al., 2007; Novosolov, Raia \& Meiri, 2013; Matson et al., 2014; Cuthbert et al., 2016), evidence of island syndrome in rodents has been found in relatively near-shore archipelagos in both freshwater and marine environments (Lomolino, 1984; Adler \& Tamarin, 1984). The Thousand Islands are an archipelago in the St. Lawrence River, whose islands are divided between Canada and the United States. The Thousand Islands region has served as the site for numerous studies of island biogeography in small mammals (Lomolino, 1982, 1984; Werden, 2012; Werden et al., 2014). Mammalian species richness in the Thousand Islands is positively related to island area (Lomolino, 1982), and the body size of meadow voles (Microtus pennsylvanicus) and shorttailed shrews (Blarina brevicauda) increases with the degree of isolation from the mainland (Lomolino, 1984). On the basis of these trends in species richness and morphology, we selected a portion of the islands belonging to Thousand Islands National Park in Ontario, Canada as our study site. As a study species, we focused on white-footed mice (Peromyscus leucopus) because they are the most abundant small mammal in Thousand Islands National Park (Werden et al., 2014), and Peromyscus has been the focus of many studies that provide the basis for island syndrome (Adler \& Levins, 1994). 
112 The current study had two aims: 1. To test if white-footed mice in the Thousand Islands

113 display characteristics of island syndrome, including greater body mass and higher relative

114 abundance than their mainland counterparts, and 2. To test if there were differences in stress

115 physiology between island and mainland mice. We tested these aims under the hypothesis that

116 island syndrome includes changes in stress physiology. To test our hypothesis, we compared

117 corticosterone (the major GC in mice and rats; Keeney, Jenkins \& Waterman, 1995) in hair

$118\left(\mathrm{CORT}_{\text {hair }}\right)$, and its metabolites in feces $\left(\mathrm{CORT}_{\text {feces }}\right)$, of white-footed mice captured at multiple

119 island and mainland locations in a near-shore archipelago; from sites in Thousand Islands

120 National Park in Ontario, Canada. We predicted that if white-footed mice in the Thousand

121 Islands were more abundant and larger than mainland mice (as expected by "island syndrome"),

122 then island mice would also have lower $\mathrm{CORT}_{\text {hair }}$ and $\mathrm{CORT}_{\text {feces }}$ levels. Because aspects of island

123 syndrome in rodents are affected by island area and distance from the mainland (Adler \& Levins,

124 1994), we also predicted that white-footed mice would have lower GC levels on the smaller and

125 more isolated islands in the archipelago. Finally, we evaluated how body mass affected CORT in

126 white-footed mice, and whether CORT varied between seasons and with population density.

127

128 MATERIALS \& METHODS

129 The Trent University Animal Care Committee (protocol numbers 23877 and 24341) approved all

130 procedures prior to working with the animals. Trapping in the Thousand Islands National Park

131 was approved via a Parks Canada Research and Collection Permit (No. 22959).

132

133 Study species and location

134 The white-footed mouse is a small, nocturnal rodent that inhabits deciduous and mixed forests in

135 the eastern United States and southern edge of Canada (Werden et al., 2014). White-footed mice

136 in Ontario breed from April - August, and females have litters of approximately 5 individuals on

137 average (Millar, Wille \& Iverson, 1979). Female white-footed mice in southern Ontario produce

138 1-4 litters per year (Harland, Blancher \& Millar, 1979). Moulting in Peromyscus precedes or

139 follows energetically costly periods such as reproduction, and begins in March in white-footed

140 mice in the nearby state of New York (Pierce \& Vogt, 1993). Our small mammal trapping period

141 coincided with the breeding season, when most individuals would be displaying their summer

142 pelage.

143 All trapping locations were located in Thousand Islands National Park in Ontario, Canada

144 (Figure 1). Selection of trapping locations was limited to locations within Thousand Islands

145 National Park, and those islands that were large enough to place trapping grids. These islands are

146 also visited by visitors to the National Park, so traps had to be placed away from walking paths

147 and campsites. We trapped on 11 islands and at 5 mainland sites during two years (2015 and

148 2016). Mainland sites were located within $2 \mathrm{~km}$ of the St. Lawrence River (Figure 1). We

Peer] reviewing PDF | (2019:06:38691:2:0:NEW 10 Jan 2020) 
149 targeted wooded areas as opposed to open fields so that relative abundance could be compared

150 between locations and to increase trapping success. Island area and distance from the mainland were calculated using ArcMap (Version 10.4.1; see Table S1).

152

\section{Small mammal trapping}

154 We trapped during three periods: summer 2015 (July - August), spring 2016 (May-June) and summer 2016 (July - August). Efforts were made to alternate between trapping on islands and mainland sites; however, weather conditions occasionally dictated access to island sites (trapping dates are provided in Table S1). Sherman live-traps (H.B. Sherman Traps, Inc., Tallahassee, FL, USA) were set $10 \mathrm{~m}$ apart in rectangular grids of varying size. The majority of grids were arranged in a 7 by 7 formation (49 traps in total), however some areas on small islands were limited by pedestrian paths, which necessitated using smaller grids ( 5 by 5 ), or in one case, transects (Mermaid Island). Hulled sunflower seeds were used as bait and natural cotton bedding was provided for warmth. Traps were set in the evening (ca. $1800 \mathrm{~h}$ ) and checked in the morning (ca. $0700 \mathrm{~h}$ ) to target the active period of white-footed mice. Trapping periods generally consisted of 2-4 nights of consecutive trapping.

Upon capture, white-footed mice were weighed $( \pm 1 \mathrm{~g})$ and a patch of hair $(\mathrm{ca} .1 \mathrm{x} 1 \mathrm{~cm})$ was shaved from the rump of each individual, above the right-hind limb using an electric razor (Remington ${ }^{\mathrm{TM}}$ Model PG6025), collecting the entire length of each shaft from the skin to the distal end of the shaft. We standardized the shaving location because hair GC levels can vary among body regions (Macbeth et al., 2010; Acker, Mastromonaco \& Schulte-Hostedde, 2018). Each white-footed mouse was ear-tagged to recognize recaptured individuals, and then released. The razor blades were cleaned with alcohol swabs between shaving each animal. Hair samples were stored in Fisherbrand ${ }^{\mathrm{TM}}$ Snap-Cap ${ }^{\mathrm{TM}}$ Flat-Top Microcentrifuge Tubes in the dark at ambient temperature (approx. $\left.22^{\circ} \mathrm{C}\right)$ until hair hormone analysis $(2-5$ months later). Coat colour and body mass were used to exclude juveniles from our analyses. Coat colour and stage were occasionally noted (grey, brown, reddish-brown or moulting) in 2015, and always noted in 2016. We identified juveniles by their grey pelage and in the absence of coat colour data, individuals $\leq 14$ g were excluded (Wolff, 1984).

White-footed mouse feces were collected from traps using forceps. Fecal samples were stored in Fisherbrand ${ }^{\mathbf{T M}}$ Snap-Cap ${ }^{\mathbf{T M}}$ Flat-Top Microcentrifuge Tubes and placed in a cooler with ice packs until they could be stored in a liquid nitrogen-cooled dry-shipper (within $6 \mathrm{~h}$ of collection). Fecal glucocorticoid metabolites are stable over the timeframe of our sample collection. For example, fecal samples maintained for 5-hours at room temperatures had similar levels as samples immediately frozen following collection (Dantzer et al., 2010). At ambient temperature, metabolites are reported to be stable for up to 48-hrs (Parnell et al., 2015). Soiled traps were cleaned with $70 \%$ ethanol between uses to ensure that the feces collected from each 
186 trap belonged to the animal caught in the trap that night. Samples were then transferred to a $-80 \mathrm{C}$

187 freezer until hormone extraction (2-9 months in freezer). At sub-zero temperatures, fecal

188 glucocorticoid metabolites are stable for at least a year (Beehner and Whitten, 2004).

189

\section{Relative Abundance}

191 As a proxy for the population density, we calculated relative abundance of white-footed mice at 192 each site during each of the 3 trapping periods. Relative abundance was calculated as catch-per193 unit-effort (CPUE), presented in number of white-footed mice captured per hundred trap-nights.

194 We corrected for tripped traps following the correction factor equation (Nelson \& Clark, 1973):

$$
\mathrm{CPUE}=\mathrm{A} \times 100 /(\mathrm{TU}-\mathrm{S} / 2)
$$

$$
\mathrm{TU}=\mathrm{P} \times \mathrm{N}
$$

where $\mathrm{A}=$ number of white-footed mice caught; $\mathrm{TU}=$ trapping units, calculated as total number of trap nights per site session; $\mathrm{P}=$ number of nights in each trapping session; $\mathrm{N}=$ number of traps set each night; and $\mathrm{S}=$ total sprung traps. This approach has been widely used in other studies of small mammal ecology (Parker et al., 2016; Gill et al., 2018; Fauteux et al., 2018).

\section{Hormone extraction and analysis}

203

The use of fecal CORT metabolites and hair CORT have been validated as measures of stress in laboratory mice (Mus musculus; Daniszová et al., 2017; Erickson, Browne \& Lucki, 2017). Hair corticosterone $\left(\mathrm{CORT}_{\text {hair }}\right)$ and fecal corticosterone metabolites $\left(\mathrm{CORT}_{\text {feces }}\right)$ were extracted with methanol (100\% for hair, $80 \%$ for feces) following Mastromonaco et al. (2014) and Stewart et al. (2018). Hair samples were cut into $5 \mathrm{~mm}$ pieces and weighed into $7 \mathrm{ml}$ glass scintillation vials. The samples were washed with $100 \%$ methanol by vortexing for $10 \mathrm{~s}$ followed by immediate removal of the methanol. Immediately thereafter, $100 \%$ methanol was added to the samples at a ratio of $0.005 \mathrm{~g} / \mathrm{ml}$. Samples were vortexed for $10 \mathrm{~s}$ and mixed for $24 \mathrm{~h}$ on a plate shaker. After $24 \mathrm{~h}$, the vials were centrifuged for $10 \mathrm{~min}$ at $2400 \mathrm{~g}$ and the supernatants were transferred into clean glass vials. Fecal samples were thawed and weighed into $7 \mathrm{ml}$ glass scintillation vials to which $80 \%$ methanol in water (v:v) was added at a ratio of $0.05 \mathrm{~g} / \mathrm{ml}$. The samples were vortexed for $10 \mathrm{~s}$ and mixed overnight on a plate shaker. The vials were then centrifuged for $10 \mathrm{~min}$ at $2400 \mathrm{~g}$ and the supernatants were transferred into clean glass vials. The supernatants from extracted hair and fecal samples were stored sealed at $-20{ }^{\circ} \mathrm{C}$ for $1-9$ months until they were evaporated and analyzed. Dried-down hair extracts (600 $\mu 1$ per sample) were reconstituted in $150 \mu \mathrm{l}$ EIA buffer $(0.1 \mathrm{mM}$ sodium phosphate buffer, $\mathrm{pH} 7.0$, containing $9 \mathrm{~g}$ of $\mathrm{NaCl}$ and $1 \mathrm{~g}$ of bovine serum albumin per litre) resulting in a 4-fold concentration. Dried-down 
To quantify $\mathrm{CORT}_{\text {hair }}$ and $\mathrm{CORT}_{\text {feces, }}$, we used an enzyme immunoassay (EIA) following

223 methods described by Baxter-Gilbert et al. (2014). Microtitre plates were coated with 0.25

$224 \mu \mathrm{g} /$ well goat anti-rabbit IgG polyclonal antibody (Sigma-Aldrich, Mississauga, ON, Canada;

$2251: 200,000$ in coating buffer, $50 \mathrm{mM}$ bicarbonate buffer, $\mathrm{pH}$ 9.6) and incubated overnight at room

226 temperature. Plates were washed with $0.05 \%$ Tween $20,0.15 \mathrm{M} \mathrm{NaCl}$ solution and blocked with

$227250 \mu \mathrm{l}$ EIA buffer for $1 \mathrm{hr}$ at room temperature. Plates were then loaded with $50 \mu \mathrm{l}$

228 corticosterone standard (Steraloids Q1550; 39-10,000 pg/ml), reconstituted extracts and controls,

229 followed by $100 \mu 1$ horseradish peroxidase conjugate $(1: 1,000,000)$ and $100 \mu 1$ corticosterone 230 antiserum (1:200,000) (antibody lot: CJM006; C. Munro, University of California, Davis, CA,

231 USA), all diluted in EIA buffer. Plates were incubated overnight at room temperature, and then

232 washed and loaded with $200 \mu 1$ of substrate solution $(0.5 \mathrm{ml}$ of $4 \mathrm{mg} / \mathrm{ml}$ tetramethylbenzidine in

233 dimethylsulphoxide and $0.1 \mathrm{ml}$ of $0.176 \mathrm{M} \mathrm{H}_{2} \mathrm{O}_{2}$ diluted in $22 \mathrm{ml}$ of $0.01 \mathrm{M}$ sodium acetate

234 trihydrate $\left[\mathrm{C}_{2} \mathrm{H}_{3} \mathrm{NaO}_{2} \cdot 3 \mathrm{H}_{2} \mathrm{O}\right], \mathrm{pH}$ 5.0). After 30 minute incubation, colour reaction was stopped

235 with $50 \mu \mathrm{H} \mathrm{H}_{2} \mathrm{SO}_{4}(1.8 \mathrm{M})$ and absorbance was measured at $450 \mathrm{~nm}$ using a spectrophotometer

236 MRX $^{\mathrm{e}}$ microplate reader, Dynex Technologies, Chantilly, VA. The assay cross-reactivities are:

237 corticosterone (100\%), desoxycorticosterone (14.25\%), and other GC metabolites $(<3 \%)$

238 (Watson et al. 2013). Inter- and intra-assay CV's were 13.9\% and 4.4\%, respectively, with 25

239 plates being run in total. Samples were run as duplicates, and only samples with $<10 \% \mathrm{CV}$ were

240 accepted (if CV $>10 \%$, the sample was re-run). Because CORT is the dominant GC in white-

241 footed mice, but is highly metabolized prior to excretion (Touma et al 2003), we refer to the

242 values obtained from fecal analysis by EIA as fecal CORT metabolites. All hormone

243 concentrations are described as ng of CORT / $g$ of feces or hair. Serial dilutions of pooled hair

244 and fecal extract showed parallel displacement with the corticosterone standard curve (hair: $\mathrm{r}=$

245 0.997, $p<0.01$; fecal: $\mathrm{r}=0.996, p<0.01$; Figure S1). The recovery of known concentrations of

246 corticosterone from mouse hair and fecal extracts were $102.7 \pm 4.3 \%$ and $83.5 \pm 5.4 \%$,

247 respectively. The measured hormone concentrations in the spiked samples correlated with the

248 expected concentrations (hair $\mathrm{r}=0.999, \mathrm{p}<0.01$; fecal $\mathrm{r}=0.998, \mathrm{p}<0.01$ ).

250 Statistical analysis

We tested all of our predictions using linear-mixed effects models, with sampling site (specific island or mainland location) as a random effect that was nested within habitat type (whether the site was on an island or on the mainland) for island-mainland comparisons. Our analyses can be broken down into three groups: island-mainland comparisons, among-island comparisons, and seasonal analyses. With the exception of our analysis of relative abundance, island-mainland comparisons were made using only summer data (July-August captures) for 2015 and 2016 (spring 2016 data were excluded). For among-island comparisons, only island capture data from summer months were used and island size and isolation were added as 
259

260

261

262

263

264

265

266

267

268

269

270

271

272

273

274

275

276

277

278

279

280

281

282

283

284

285

286

287

288

289

290

291

292

293

294

295

covariates. For seasonal analyses, only 2016 data were used because we had both spring and summer data for that year. Habitat type (island-mainland) and island size and isolation were dropped from testing for seasonal effects on morphological and physiological parameters. All corticosterone and body mass data were ln-transformed, and island area and distance to the mainland were $\log _{10}$ transformed in all analyses to improve the normality of model residuals. Any visibly pregnant females ( $\mathrm{n}=15$; Millar, Wille \& Iverson, 1979) were excluded from all analyses (Novikov \& Moshkin, 1998; Young et al., 2006), with the exception of relative abundance. If an individual was captured more than once, only data from the first capture were used.

In all analyses, two-way interactions were included in initial models for those variables that were expected to be biologically relevant (sex and season) and pertinent to our hypotheses (habitat type and island measurements). Sampling site was retained as a random effect in all models and nested within habitat type for island-mainland comparisons. The full model for the island-mainland comparison of relative abundance included habitat type, year and season with all two-way interactions. The full model for comparing relative abundance among islands included year and season with their interaction, and covariates for island size and isolation with their interaction. The full model for the island-mainland comparison of body mass included habitat type, sex and year with all two-way interactions. The full model for comparing body mass among islands included sex and year with their interaction, and covariates for island size and isolation with their interaction. The full models for the island-mainland comparisons of both $\mathrm{CORT}_{\text {hair }}$ and $\mathrm{CORT}_{\text {feces }}$ included habitat type, sex and year with all two-way interactions, and covariates for relative abundance and body mass. The full models for comparing $\mathrm{CORT}_{\text {hair }}$ and $\mathrm{CORT}_{\text {feces }}$ among islands included sex and year with their interaction, covariates for body mass, relative abundance, and island size and isolation, and the interaction between island size and isolation. The full model for comparing $\mathrm{CORT}_{\text {hair }}$ and $\mathrm{CORT}_{\text {feces }}$ between seasons included sex and season with their interaction, and body mass as a covariate.

To reduce model complexity, non-significant two-way interactions $(p>0.05)$ were dropped to test the variables of greatest interest (habitat type, sex, and season). Two-way interactions were dropped in order of largest $p$-value, and then remaining fixed effects were also dropped in that order. Habitat type, sex, year and island size and distance to the mainland (for among island analyses), were always retained, with the exception of testing seasonal variation. Full models (not including two-way interactions) were presented if model reduction did not result in significance of main effects.

Analyses were conducted using RStudio (Version 0.99.484, RStudio, Inc). Linear-mixed effects models were fit with the lmer function of the "lme4" package (Version 1.1.7) using restricted maximum likelihood (REML) and non-standardized variables. Results, including $p$ values, $t$-values, and Satterthwaite approximations to degrees of freedom, were obtained using 
296 the "summary" function of the "ImerTest" package (Version 2.0.20; Kuznetsova, Brockhoff \&

297 Christensen, 2016). Goodness of fit was assessed using marginal ${ }_{(\mathrm{M})}$ and conditional ${ }_{(\mathrm{C})}$ pseudo

$298 R^{2}$ values ( $R^{2}{ }_{\text {GLMM }}$; Nakagawa \& Schielzeth, 2013) calculated with the "r.squaredGLMM"

299 function in the "MuMIn" package (Version 1.13.4; Barton, 2016). $R^{2}{ }_{\mathrm{GLMM}(\mathrm{M})}$ represents the

300 proportion of the variation explained by the fixed effects alone, and $R_{\mathrm{GLMM}(\mathrm{C})}^{2}$ represents the

301 proportion of variation explained by both the fixed and random effects (Nakagawa \& Schielzeth,

302 2013). Correlations were tested using the "cor.test" function in $\mathrm{R}$, which calculates a $p$-value

303 based on Fisher's Z transformation.

304

305

\section{RESULTS}

306

We caught 408 individual white-footed mice during 2015-2016; 17 individuals were recaptured

307

308

309

310

311

312

313

314

315

316

317

318

319

320

321

322

323

324

325

326

327

328

329

330

331

332 between trapping periods. Trapping success was highly variable across sampling sites, and there were no consistent trapping patterns between mainland and island sites. For example, based on overall CPUE, trapping was more successful on some islands than on the mainland (as would be predicted via the "island rule"); however, on some islands there were zero captures during some trapping periods while mainland sites always yielded captures (Table S2). More traps were tripped at island sites (mean $\pm \mathrm{SD} ; 38 \% \pm 10.8 \%$ ) than mainland sites $(23 \% \pm 12.8 \%)$, and it was likely that trap disturbance contributed to the high degree of variation in trapping success across habitat types. Although trapping effort varied among sites due to some sites only being trapped during one sampling period, trapping effort was approximately equal between the two habitat types. Mainland sites received an average of $288 \pm 151.1$ trap nights across the entire sampling program, and island sites received an average of $264 \pm 147.6$ trap nights (Table S1)

\section{Relative abundance of mice did not differ between islands and the mainland}

The final model for the island-mainland comparison of relative abundance of whitefooted mice was reduced from the full model by removing two-way interactions. Contrary to expectations of the island rule, there was no difference in relative abundance of island and mainland white-footed mice ( $p=0.667$, Table 1$)$. Relative abundance differed between years; it was 44\% higher in summer 2015 than in summer 2016 ( $p=0.012$; Table 1). In 2016, in which we had data for both spring and summer, relative abundance was $74 \%$ higher in the summer than the spring ( $p=0.033$; Table 1). The final model for the among-islands comparison of relative abundance of white-footed mice was reduced from the full model by removing two-way interactions. CPUE decreased on all islands between 2015 and $2016(p=0.011)$. There was no effect of island area $(p=0.603)$ nor distance from the mainland $(p=0.442$, Table 1$)$ on relative abundance of white-footed mice.

Summer abundance of white-footed mice from individual sampling sites was positively correlated between years (11 sites, $\mathrm{r}=0.852, t_{9}=4.87, p=0.0009$; Figure 2 ). Although there was 
333 a general decrease in relative abundance between years across habitat types, CPUE was nearly

334 equal between years for the three mainland sites that were trapped during both summers (Figure

335 2). This is demonstrated in Figure 2, where CPUE values for mainland sites fall close to the

336 dotted line which represents the relationship if abundances were equal between years. All

337 resampled island sites fall below that line, showing a decrease in abundance between years for

338 island mice (Figure 2).

339

340 Body mass did not differ between island and mainland mice

341 The final model for the island-mainland comparison of body mass of white-footed mice was

342 reduced from the full model by removing two-way interactions. Contrary to expectations of the

343 island rule, white footed mice from the Thousand Islands $(\mathrm{n}=209)$ were not heavier than on the

344 mainland ( $\mathrm{n}=92 ; p=0.804$; Table 2; Figure 3 ), nor did body mass differ between years ( $p=$

$3450.875)$. Male mice $(\mathrm{n}=181 ;$ mean $\pm \mathrm{SD} ; 21.0 \pm 3.7 \mathrm{~g})$ were significantly heavier than females $(\mathrm{n}$

$346=120 ; 20.2 \pm 4.4 \mathrm{~g})$ across habitat types $(p=0.020)$; however, the average difference was less

347 than $1 \mathrm{~g}$, and the model had little explanatory power $\left(R_{\mathrm{GLMM}(\mathrm{M})}^{2}=0.02 ; R_{\mathrm{GLMM}(\mathrm{C})}=0.04\right.$; Table

348 2).

349

350

351

352

353

354

355

356

357

358

359

360

361

362

363

The final model for the among-islands comparison of body mass of white-footed mice was reduced from the full model by removing two-way interactions. For island mice, there was no effect of island area $(p=0.476$, Table 2$)$ nor distance from the mainland $(p=0.385)$ on body mass. Again, males were heavier than females on islands $(p=0.019)$; however, this effect explained little variation overall $\left(R_{\mathrm{GLMM}(\mathrm{M})}^{2}=0.04 ; R_{\mathrm{GLMM}(\mathrm{C})}=0.04\right.$; Table 2$)$.

\section{Hair corticosterone did not differ between island and mainland mice, but increased with} body mass

The final model for the island-mainland comparison of $\mathrm{CORT}_{\text {hair }}$ of white-footed mice was reduced from the full model by removing two-way interactions. There was no difference between $\mathrm{CORT}_{\text {hair }}$ of island $(\mathrm{n}=188)$ and mainland $(\mathrm{n}=82)$ white-footed mice $(p=0.4080$; Table 3 , Figure 3). Sex $(p=0.9611)$, year of capture $(p=0.5159)$ and relative abundance $(p=0.3837)$ also had no effect on $\mathrm{CORT}_{\text {hair }}$ (Table 3$)$. However, $\mathrm{CORT}_{\text {hair }}$ increased with body mass ( $p=$ 0.0011 ; Table 3; Figure 4). There was a small effect size for this model $\left(R^{2}{ }_{\mathrm{GLMM}(M)}=0.05\right.$, $R^{2}{ }_{\mathrm{GLMM}(C)}=0.14$; Table 3).

The final model for the among-islands comparison $\mathrm{CORT}_{\text {hair }}$ of white-footed mice was reduced from the full model by removing two-way interactions. Focusing only on island mice, neither island area $(p=0.4807$, Table 3$)$ nor distance from the mainland $(p=0.6092)$ predicted $\mathrm{CORT}_{\text {hair }}$ levels. However, body mass continued to be a significant predictor of $\mathrm{CORT}_{\text {hair }}$ for the 
370 Fecal corticosterone metabolites did not differ between island and mainland mice

371 The final model for the island-mainland comparison of $\mathrm{CORT}_{\text {feces }}$ of white-footed mice was

372 reduced from the full model by removing two-way interactions, relative abundance and ln-

373 transformed body mass, each of which had no significant effect. There was no difference

374 between $\mathrm{CORT}_{\text {feces }}$ of island $(\mathrm{n}=160)$ and mainland $(\mathrm{n}=49)$ white-footed mice during the

375 summer months ( $p=0.8578$; Table 4). Male mice had lower $\operatorname{CORT}_{\text {feces }}$ than females $(p=0.0492$;

376 Table 4; Figure 3) and $\mathrm{CORT}_{\text {feces }}$ was higher in the summer of 2016 than summer $2015(p<$

377 0.0001; Table 4).

378 The final model for the among-islands comparison $\mathrm{CORT}_{\text {feces }}$ of white-footed mice was

379 reduced from the full model by removing two-way interactions, relative abundance and $\ln$ -

380 transformed body mass, each of which had no significant effect. There was no effect of either

381 island area $(p=0.9440$, Table 4$)$ nor distance from the mainland $(p=0.6320)$ on CORT $_{\text {feces }}$

382 (Table 4). CORT $_{\text {feces }}$ levels were higher in 2016 than in 2015 ( $\left.p<0.0001\right)$, but unlike the model

383 for the island-mainland comparison, there was no difference between sexes for $\operatorname{CORT}_{\text {feces }}(p=$

384 0.1320; Table 4).

385

386

Hair corticosterone levels were lower in spring than summer for females, but not for males The full model was retained for comparing $\mathrm{CORT}_{\text {hair }}$ of white-footed mice between seasons. For $\mathrm{CORT}_{\text {hair }}$ of white-footed mice collected in $2016(\mathrm{n}=147)$, when we had data from both spring and summer, there was a significant interaction between sex and season $(p=0.0009$, Table 5). Female $\mathrm{CORT}_{\text {hair }}$ was lower in spring than in summer, while male $\mathrm{CORT}_{\text {hair }}$ did not differ between seasons (Figure 5). This model had a greater effect size than other models of factors affecting $\mathrm{CORT}_{\text {hair }}\left(R^{2}{ }_{\mathrm{GLMM}(\mathrm{M})}=0.22, R^{2} \mathrm{GLMM}_{(\mathrm{M})}=0.35\right.$; Table 5), indicating a relatively strong effect of season on $\mathrm{CORT}_{\text {hair }}$ for female white-footed mice.

\section{Fecal corticosterone metabolites of both sexes were lower in spring than summer}

To explore seasonal effects on $\mathrm{CORT}_{\text {feces }}$ we focused on 2016, for which we had data from both spring and summer $(\mathrm{n}=71)$. The final model for comparing $\mathrm{CORT}_{\text {feces }}$ levels between seasons was reduced from the full model by removing two-way interactions and $\ln$-transformed body mass. Both sexes had lower CORT $_{\text {feces }}$ levels in spring than in summer $(p<0.0001$, Table 6), but there was no difference between sexes ( $p=0.168$; Table 6). The interaction between sex and season, that had influenced $\mathrm{CORT}_{\text {hair }}$ levels, did not influence $\mathrm{CORT}_{\text {feces }}$ levels $\left(t_{63}=-1.423, p=\right.$ $0.160)$ so it was dropped from the model.

403

\section{Corticosterone in hair and related metabolites in feces were positively correlated}

405

$\mathrm{CORT}_{\text {hair }}$ values from all collected samples $(\mathrm{n}=333)$ ranged from 5.1-398.6 $\mathrm{ng} / \mathrm{g}$, with a median 406 level of $79.8 \mathrm{ng} / \mathrm{g}$. Values for $\mathrm{CORT}_{\text {feces }}$ from all collected samples $(\mathrm{n}=303)$ ranged from 30.5- 
$4071239.8 \mathrm{ng} / \mathrm{g}$, with a median of $335.4 \mathrm{ng} / \mathrm{g}$. A simple correlational analysis suggests $\mathrm{CORT}_{\text {hair }}$ and $408 \mathrm{CORT}_{\text {feces }}$ of white-footed mice were significantly, although weakly, positively correlated $(\mathrm{r}=$ $4090.16, t_{178}=2.196, p=0.015$; Figure 6).

410

\section{DISCUSSION}

\section{White-footed mice do not display island syndrome in the Thousand Islands}

413 Despite the tendency for island wildlife to display morphological and physiological adaptations 414 to insularity (Matson et al., 2014; Holding et al., 2014; Spencer et al., 2017), white-footed mice 415 in the Thousand Islands did not differ in any of these characteristics from their mainland 416 conspecifics. White-footed mice on islands did not display higher relative abundance than 417 mainland mice in disagreement with the general prediction that rodents exhibit particularly high 418 densities on islands (Adler \& Levins, 1994; Crespin, Duplantier \& Granjon, 2012; Cuthbert et 419 al., 2016), which has been observed for other small vertebrates as well (Novosolov, Raia \& 420 Meiri, 2013; Sale \& Arnould, 2013). Additionally, island sites showed a trend toward a greater 421 decrease in relative abundance compared to mainland sites for the two years that we sampled 422 (Figure 2). This trend may not have resulted in a significant interaction effect between habitat 423 type and year due to the small number of mainland sites that were sampled during both summers. 424 Although this trend only represents two years of data, these results differ from Adler and Levins' 425 (1994) description of island syndrome, and studies showing that island rodents are more stable, 426 and less prone to drastic changes in abundance than mainland populations (Gliwicz, 1980;

427 Herman \& Scott, 1984; Tamarin \& Sheridan, 1987). The stability of high population densities on 428 oceanic islands has been partially attributed to marine resource subsidies and climate stability 429 compared to continental systems (Stapp \& Polis, 2003; Barrett et al., 2005; Sale \& Arnould, 430 2013); factors that do not apply when comparing rodents on the near-shore Thousand Islands to 431 the adjacent mainland.

432 Small mammals on islands often exhibit large body size (Lomolino et al., 2012; Sale \& 433 Arnould, 2013; Harper \& Rutherford, 2016); however, we did not detect a difference in body 434 mass between island and mainland white-footed mice in the Thousand Islands. This was 435 surprising, because a high degree of isolation is not necessarily required for demographic or 436 body mass differences among Peromyscus populations to occur. Adler, Wilson \& Derosa (1986) 437 detected a relationship between population density and island isolation of white-footed mice on 438 coastal islands located between $16-1,046 \mathrm{~m}$ from shore (by comparison, we had large samples 439 of mice from Thwartway and Grenadier islands, which were 2,837 and 1,038 $\mathrm{m}$ from the 440 mainland, respectively; Table S1). Deer mice on Anaho Island in Pyramid Lake, Nevada 441 (approximately 1,000 $\mathrm{m}$ from the mainland) have significantly greater body length than mainland 442 mice (Kuhn, Gienger \& Tracy, 2016). 
444 These negative results regarding patterns between body size and island biogeography do not 445 agree with results for other small mammals in the Thousand Islands. Lomolino (1984) found that 446 the body size of meadow voles (Microtus pennsylvanicus) and short-tailed shrews (Blarina 447 brevicauda) in the Thousand Islands increased as distance from the mainland increased. This 448 pattern was attributed to the ability of larger individuals to cross greater distances on ice during 449 the winter, and subsequent founder effects of large individuals reaching more distant islands 450 (Lomolino, 1984). The islands sampled by Lomolino might have been better suited to 451 investigating patterns related to isolation because they were less closely clustered together than 452 those that we sampled. The clustered nature of many of the islands in our study makes their true 453 degree of isolation difficult to determine.

454 On average, we found that male white-footed mice were heavier than females for both 455 island and mainland habitats. This result is consistent with data from laboratory raised white456 footed mice (Dewsbury et al., 1980). Greater male body mass has also been found for deer mice 457 collected in the field (Schulte-Hostedde, Millar \& Hickling, 2001). Male-biased sexual size 458 dimorphism is widespread in mammals (Isaac, 2005), and often explained by sexual selection 459 favouring large male body size through competition between males for access to mates (Trivers, 460 1972).

461

462

463

464

465

466

467

468

469

470

471

472

473

474

475

\section{No difference in CORT levels between island and mainland mice}

We predicted that white-footed mice on islands would have lower $\mathrm{CORT}_{\text {hair }}$ and $\mathrm{CORT}_{\text {feces }}$ levels than mainland mice, however these predictions were not supported. There was also no effect of island size or distance from the mainland on CORT levels. This result may not be surprising, given that we found no evidence of island syndrome. The lack of an island effect on any of these characteristics in the Thousand Islands suggests either that island white-footed mice experience similar stressors and pressures to mice on the mainland, or that there is a high degree of gene flow between island and mainland white-footed mice. Either of these explanations could be caused by the short distances between islands and from the islands to the mainland, and the freezing of the river in the winter.

The proximity of these islands to the mainland, and to one another, may mean that insular white-footed mice experience similar levels of inter-specific competition to mainland mice. Although the diet of white-footed mice is based primarily on insects, they also forage heavily on seeds (Manson \& Stiles, 1998). Release from competition with larger granivores, such as squirrel species (Sciuridae), could result in increased body size of Peromyscus (Nupp \& Swihart, 1996). However, we caught red squirrels (Tamiasciurus hudsonicus) and flying squirrels (Glaucomys spp.) on near-shore islands (Constance and Georgina), and observed grey squirrels (Sciurus carolinensis) on more isolated islands (McDonald and Thwartway; N. Stewart, Personal Observation). Although we did not catch eastern chipmunks on any islands, they have previously 
481 been caught on islands in the archipelago (Werden et al., 2014). Given the presence of other

482

483

484

485

486

487

488

489

490

491

492

493

494

495

496

497

498

499

500

501

502

503

504

505

506

507

508

509

510

511

512

513

514

515

516

517

small mammal species, release from competition might not be a factor on these islands.

The proximity of these islands to shore might cause equal predation risk on the islands and the mainland. Small terrestrial predators, such as weasels (Mustela spp.), might occur in low numbers on some of the islands (Grenadier Island; Werden et al., 2014). however, avian predators can readily access islands to prey on mice. Coyotes (Canis latrans), red foxes (Vulpes vulpes), and raccoons (Procyon lotor) also inhabit or periodically forage on islands by crossing ice in the winter (Coleman, 1979). We experienced somewhat higher numbers of tripped traps on islands than at mainland trapping sites. We visually observed raccoons on a number of the islands, and attribute much of the disturbance to raccoons instead of missed white-footed mice, given that traps were often wide open and moved from their original set point (Grant, 1976). Racoons might have been more likely to find traps within the boundaries of islands than mainland expanses, given the small size of most the islands in this study compared to typical raccoon home range size (100-300 ha; Kaufmann 1982).

High gene flow among islands and the mainland in the Thousand Islands could be attributed to the ability of white-footed mice to swim short distances or cross ice in the winter (Lomolino, 1989), and to disperse via transport onboard boats. Despite these dispersal mechanisms, genetic dissimilarity between Peromyscus populations can occur at short distances ( $<500 \mathrm{~m}$ from mainland or large island) in other freshwater archipelagos (Landry \& Lapointe, 2001; Vucetich et al., 2001). Genetic studies of white-footed mice in the Thousand Islands would provide greater understanding of the degree of similarity between separate populations in the archipelago.

Studies of the island rule attribute a range of factors to the degree to which body size of small mammals on islands differs from their mainland relative, including island isolation, latitude, and marine subsidies (foraging on aquatic prey; Lomolino et al., 2012). Rainfall has also been attributed to increased body size of small mammals, and used as evidence of the island rule being more of a "resource rule" (McNab, 2010). It is because of this range of explanations for observed island-mainland differences that we were drawn to study island rodents in a near-shore archipelago, where climatic and ecological variation is limited between island and mainland sites. However, based on our results, a significant degree of ecological isolation may be required for island syndrome to be detectable across an archipelago.

\section{Hair corticosterone increased with body mass}

Body mass was a positive predictor of $\mathrm{CORT}_{\text {hair }}$ in white-footed mice, but not $\mathrm{CORT}_{\text {feces}}$, which suggests this might be a hair-specific CORT observation, as opposed to representative of baseline CORT levels. Because body mass is positively correlated with age in Peromyscus (Chappell, 2003), the positive relationship between $\mathrm{CORT}_{\text {hair }}$ and body mass might be indicative 
518 of a relationship between mouse age, moulting, and $\mathrm{CORT}_{\text {hair }}$ levels. Moulting in Peromyscus

519 occurs before or following energetically demanding time periods, such as breeding (Pierce \&

520 Vogt, 1993), although some hair replacement likely occurs year-round outside of complete

521 moults as in deer mice (Tabacaru, Millar \& Longstaffe, 2011). Moulting is in part regulated by

522 CORT, because steroid hormones have an inhibitory effect on moulting in Peromyscus

523 (Garwood \& Rose, 1995). As a result, hairs grown during complete moults might have relatively

524 lower CORT concentrations than replacement hairs grown following a complete moult. This

525 would result in heavier individuals (which are likely older and have increased in mass since their

526 last moult) having higher $\mathrm{CORT}_{\text {hair }}$ when compared with younger mice that have more recently

527 grown their adult pelage. Testing this relationship would require more specific knowledge

528 concerning the exact age of each mouse, and time since their last moults.

529 In American pika (Ochotona princeps), hair CORT was strongly influenced by body size

530 (measured by cranial diameter; Waterhouse et al., 2017), but in the opposite direction compared

531 to white-footed mice. Larger American pikas had lower hair CORT, which the authors attributed

532 to the negative relationship between mass-specific metabolic rate and GCs (Haase, Long \&

533 Gillooly, 2016). The conflicting directionalities of relationships between hair CORT and body

534 size for small mammals demonstrate the need for more studies concerning internal factors

535 affecting hair GCs.

536 Hair GC levels are an integrative measure of HPA activity, because they will reflect both

537 an individual's phenotype related to their baseline GC levels (Fairbanks et al., 2011), but can

538 also be influenced by an animal's exposure to stressors (Bryan et al., 2015; Scorrano et al.,

539 2015). Because the two measures are representative of different time frames, it might not be

540 surprising that CORT in hair and its related metabolites in feces are not correlated with the same

541 measures (body mass and condition), and demonstrate different seasonal patterns. We did find,

542 however, that $\mathrm{CORT}_{\text {hair }}$ and $\mathrm{CORT}_{\text {feces }}$ were positively correlated for white-footed mice. Such

543 correlations presumably represent the influence of individuals' baseline GC levels on both

$544 \mathrm{CORT}_{\text {hair }}$ and $\mathrm{CORT}_{\text {feces }}$, however, the relatively weak correlation may reflect matrix-specific

545 time-frames of GC secretion.

546

547

\section{Sex-specific seasonal variation in corticosterone}

548

549

Seasonal differences in GC levels are common among vertebrates (Romero, 2002).

550

$\mathrm{CORT}_{\text {feces }}$ levels of white-footed mice of both sexes were higher in the summer than the spring

551

(Table 6, Figure 5B), in agreement with previous studies of Peromyscus (Harper \& Austad, $2000,2001)$. High summer $\mathrm{CORT}_{\text {feces }}$ levels could be attributed to increased GC levels

552 associated with reproduction (Harper \& Austad, 2001); however, breeding occurs in whitefooted mice during early spring and lasts throughout the summer months (Pierce \& Vogt, 1993). 554 Alternatively, high summer $\mathrm{CORT}_{\text {feces }}$ levels could be caused by increased abundance of white- 
555 footed mice compared to the spring (Hayssen, Harper \& DeFina, 2002), which is consistent with 556 our finding that abundance was higher in the summer than the spring in the Thousand Islands.

557 Although we did not find a relationship between CORT and relative abundance across sites,

558 CORT and population density may be correlated within areas as densities change during annual 559 cycles.

560 In contrast to data for $\mathrm{CORT}_{\text {feces}}$, only female white-footed mice showed seasonal variation in $\mathrm{CORT}_{\text {hair, }}$, increasing from spring to summer (Table 5, Figure 5A). Male $\mathrm{CORT}_{\text {hair }}$

562 did not differ between seasons. The contrasting sex-specific results between $\mathrm{CORT}_{\text {feces }}$ and

$563 \mathrm{CORT}_{\text {hair }}$ patterns might be the result of the two measures differing in their representative time-

564 scales of CORT secretion (Mastromonaco et al., 2014). Similar to our proposed explanation of

565 the relationship between $\mathrm{CORT}_{\text {hair }}$ and body mass, it is important to consider the effect that

566 CORT has on hair growth. Female deer mice have been observed developing seasonal moults

567 during pregnancy; however, moulting ceased following the birth of their young (Collins, 1923).

568 If hair growth in in adult female white-footed mice occurs during pregnancy (similar to deer

569

570

571

572

573

574

575

576

577

578

579

580

581

582

583

584

585

586

587

588

589

590

591 mice), our observation of low $\mathrm{CORT}_{\text {hair }}$ in females may represent low CORT levels during spring pregnancies. Low CORT during pregnancy occurs in laboratory rodents and it has been suggested that attenuation of the HPA axis during pregnancy protects fetuses from adverse effects of high GCs (Reeder \& Kramer, 2005; Brunton, Russell \& Douglas, 2008). Although we did not assess the influence of reproductive condition on $\mathrm{CORT}_{\text {hair, }}$ a study focused on the relationship between reproductive condition and $\mathrm{CORT}_{\text {hair }}$ in wild rodents would be useful.

Sex differences in GC levels between seasons occur in other wild rodents and are attributed to interactions between GCs and sex hormones, and differences in parental behaviour (Romero et al., 2007; Schradin, 2008; Bauer et al., 2014). In addition to reproductive influences on $\mathrm{CORT}_{\text {hair }}$, higher female $\mathrm{CORT}_{\text {hair }}$ levels could be attributed to increased aggression among territorial females when population density increases during the summer (Wolff, 1993). The significant interaction that we observed between sex and season on $\mathrm{CORT}_{\text {hair }}$ raises the question of why males did not differ as much as females. The contrasting results between sexes shown for $\mathrm{CORT}_{\text {feces }}$ and $\mathrm{CORT}_{\text {hair }}$ emphasize the importance of considering the timeline represented by the sample material.

\section{CONCLUSIONS}

The two aims of our study were: 1 . To test if white-footed mice in the Thousand Islands display characteristics of island syndrome, including greater body mass and higher relative abundance than their mainland counterparts, and 2. To test if there were also differences in stress physiology between island and mainland mice. Local populations of white-footed mice in the Thousand Islands did not differ systematically in their abundance, body mass, or hair and fecal 
592 GC levels, compared with white-footed mice on the nearby mainland. We suggest this may be 593 due to the relatively short distances between the islands and the mainland, the clustered nature of 594 the islands, and that the St. Lawrence River freezes during the winter allowing for possible 595 movement of mice and predators between islands and the mainland. Because we found no island596 mainland differences in either body mass or GCs, our results leave open the possibility that on 597 more isolated islands, where the community structure is distinctly different from mainland 598 habitats, decreased interspecific competition and predation may cause changes in the stress 599 physiology of rodents. However, such studies would need to account for the many variables 600 (temperature, precipitation, and day length) that differ between more distantly-spaced island and 601 mainland habitats. Although our initial predictions were not supported, our incidental findings of 602 a relationship between body mass and $\mathrm{CORT}_{\text {hair, }}$ and that measures of stress differed with sex, 603 season, and matrix (hair or feces) emphasizes the complexity of inferring physiological state 604 from hormonal profiles.

605

606

\section{ACKNOWLEDGEMENTS}

We thank Chantelle Penny, Tess Ward and Don Stewart for assistance with field work, Christine Gillman and Stephanie Matteer for assistance with hormone analysis, Gabriel Huebsch for guidance with spatial analysis and map-making, and Aaron Shafer, Jeff Bowman, Jim Schaefer, and three anonymous referees for comments on previous drafts of the manuscript.

612

\section{ADDITIONAL INFORMATION AND DECLARATIONS}

\section{Author Contributions}

- Nathan D. Stewart designed and conducted the field program, processed samples, analyzed the data, prepared the figures and tables, authored the drafts, and approved the final draft.

621

622

623

624

625

626

627

- Gabriela F. Mastromonaco supervised the hormone analyses, and reviewed the data and manuscript drafts, and approved the final draft.

- Gary Burness designed the experiments, edited drafts, and approved the final draft.

\section{REFERENCES}

Acker M, Mastromonaco G, Schulte-Hostedde AI. 2018. The effects of body region, season and external arsenic application on hair cortisol concentration. Conservation Physiology 6. DOI: 10.1093/conphys/coy037. 
629 Adler GH, Levins R. 1994. The Island Syndrome in Rodent Populations. The Quarterly Review 630 of Biology 69:473-490.

631 Adler GH, Tamarin RH. 1984. Demography and reproduction in island and mainland white-

632 footed mice (Peromyscus leucopus) in southeastern Massachusetts. Canadian Journal of Zoology 62:58-64. DOI: 10.1139/z84-011.

Adler GH, Wilson ML, Derosa MJ. 1986. Influence of Island Area and Isolation on Population Characteristics of Peromyscus leucopus. Journal of Mammalogy 67:406-409. DOI: $\underline{10.2307 / 1380899 .}$.

Arens A, McNab BK. 2001. The comparative energetics of caviomorph rodents. Comparative Biochemistry and Physiology Part A 130: 105-122.

Barrett K, Anderson WB, Wait DA, Grismer LL, Polis GA, Rose MD. 2005. Marine subsidies alter the diet and abundance of insular and coastal lizard populations. Oikos 109:145-153. DOI: 10.1111/j.0030-1299.2005.13728.x.

Bartoń K. 2016. MuMIn: Multi-Model Inference. Available: https://cran.rproject. org/web/packages/MuMIn/index.html.

Bauer CM, Hayes LD, Ebensperger LA, Romero LM. 2014. Seasonal variation in the degu (Octodon degus) endocrine stress response. General and Comparative Endocrinology 197:26-32. DOI: 10.1016/j.ygcen.2013.11.025.

Beehner JC, Whitten PL. 2004. Modifications of a field methods for fecal steroid analysis in baboons. Physiology \& Behavior 82: 269-277.

Blackburn TM, Cassey P, Duncan RP, Evans KL, Gaston KJ. 2004. Avian Extinction and Mammalian Introductions on Oceanic Islands. Science 305:1955-1958. DOI: 10.1126/science. 1101617.

Blondel DV, Wallace GN, Calderone S, Gorinshteyn M, St. Mary CM, Phelps SM. 2016. Effects of population density on corticosterone levels of prairie voles in the field. General and Comparative Endocrinology 225:13-22. DOI: 10.1016/j.ygcen.2015.09.002.

Brunton PJ, Russel JA, Douglas AJ. 2008. Adaptive responses of the maeternal hypothalamicpituitary-adrenal axis during pregnancy and lactation. Journal of Neuroendocrinology 20(6):764-776.

Bryan HM, Smits JEG, Koren L, Paquet PC, Wynne-Edwards KE, Musiani M. 2015. Heavily hunted wolves have higher stress and reproductive steroids than wolves with lower hunting pressure. Functional Ecology 29:347-356. DOI: 10.1111/1365-2435.12354.

\section{Cattet M, Macbeth BJ, Janz DM, Zedrosser A, Swenson JE, Dumond M, Stenhouse GB.} 2014. Quantifying long-term stress in brown bears with the hair cortisol concentration: a biomarker that may be confounded by rapid changes in response to capture and handling. Conservation physiology 2. 
665 Chappell MA. 2003. Age and aerobic performance in deer mice. Journal of Experimental

666

667

668

669

670

671

672

673

674

675

676

677

678

679

680

681

682

683

684

685

686

687

688

689

690

691

692

693

694

695

696

697

698

699

700 Biology 206:1221-1231. DOI: 10.1242/jeb.00255.

Clinchy M, Zanette L, Boonstra R, Wingfield JC, Smith JNM. 2004. Balancing food and predator pressure induces chronic stress in songbirds. Proceedings of the Royal Society B: Biological Sciences 271:2473-2479. DOI: 10.1098/rspb.2004.2913.

Clinchy M, Zanette L, Charlier TD, Newman AEM, Schmidt KL, Boonstra R, Soma KK. 2011. Multiple measures elucidate glucocorticoid responses to environmental variation in predation threat. Oecologia 166:607-614. DOI: 10.1007/s00442-011-1915-2.

Coleman DJ. 1979. A Survey of the Small Mammals of the St. Lawrence Islands National Park. Parks Canada.

Collins HH. 1923. Studies of the pelage phases and of the nature of color variations in mice of the genus Peromyscus. Journal of Experimental Zoology Part A: Ecological Genetics and Physiology 38(1):45-107.

Crespin L, Duplantier J-M, Granjon L. 2012. Demographic aspects of the island syndrome in two Afrotropical Mastomys rodent species. Acta Oecologica-International Journal of Ecology 39:72-79. DOI: 10.1016/j.actao.2012.01.002.

Cuthbert RJ, Wanless RM, Angel A, Burle M-H, Hilton GM, Louw H, Visser P, Wilson JW, Ryan PG. 2016. Drivers of predatory behavior and extreme size in house mice Mus musculus on Gough Island. Journal of Mammalogy:gyv199. DOI: 10.1093/jmammal/gyv199.

Daniszová K, Mikula O, Macholán M, Pospísilová I, Vošlajerová BB, Hiadlovská Z. 2017. Subspecies-specific response to ACTH challenge test in the house mouse (Mus musculus). Endocrinology 252: 186-192.

Dantzer B, McAdam AG, Palme R, Fletcher QE, Boutin S, Humphries MM, Boonstra R. 2010. Fecal cortisol metabolite levels in free-ranging North American red squirrels: assay validation and the effects of reproductive condition. General and Comparative Endocrinology 167: 279-286.

Dantzer B, Fletcher QE, Boonstra R, Sheriff MJ. 2014. Measures of physiological stress: a transparent or opaque window into the status, management and conservation of species? Conservation Physiology 2:cou023.

Dettmer AM, Novak MA, Meyer JS, Suomi SJ. 2014. Population density-dependent hair cortisol concentrations in rhesus monkeys (Macaca mulatta). Psychoneuroendocrinology 42:59-67. DOI: 10.1016/j.psyneuen.2014.01.002.

Dewsbury DA, Baumgardner DJ, Evans RL, Webster DG. 1980. Sexual Dimorphism for Body Mass in 13 Taxa of Muroid Rodents under Laboratory Conditions. Journal of Mammalogy 61:146-149. DOI: 10.2307/1379975. 
701 Erickson RL, Browne CA, Lucki I. 2017. Hair corticsterone measurement in mouse models of

702

703

704

705

706

707

708

709

710

711

712

713

714

715

716

717

718

719

720

721

722

723

724

725

726

727

728

729

730

731

732

733

734

735 type 1 and type 2 diabetes mellitus. Physiology and Behavior 178:166-171. DOI: 10.1016/j.physbeh.2017.01.018.

Fairbanks LA, Jorgensen MJ, Bailey JN, Breidenthal SE, Grzywa R, Laudenslager ML. 2011. Heritability and genetic correlation of hair cortisol in vervet monkeys in low and higher stress environments. Psychoneuroendocrinology 36:1201-1208. DOI: 10.1016/j.psyneuen.2011.02.013.

Fauteux D, Gauthier G, Mazerolle MJ, Coallier N, Bêty J, Berteaux D. 2018. Evaluation of invasive and non-invasive methods to monitor rodent abundance in the Arctic. Ecosphere 9:e02124. DOI: 10.1002/ecs2.2124.

Foster JB. 1964. Evolution of Mammals on Islands. Nature 202:234-235. DOI: 10.1038/202234a0.

Garwood T, Rose J. 1995. Effects of bilateral adrenalectomy on initiation of fur growth cycles in the deer mouse (Peromyscus maniculatus). Laboratory Animal Science 45:564-566.

Gill NS, Yelenik S, Banko P, Dixon CB, Jaenecke K, Peck R. 2018. Invasive rat control is an efficient, yet insufficient, method for recovery of the critically endangered Hawaiian plant hau kuahiwi (Hibiscadelphus giffardianus). PloS one 13:e0208106.

Gliwicz J. 1980. Island Populations of Rodents: Their Organization and Functioning. Biological Reviews 55:109-138. DOI: 10.1111/j.1469-185X.1980.tb00690.x.

Good T, Khan M., Lynch J. 2003. Biochemical and physiological validation of a corticosteroid radioimmunoassay for plasma and fecal samples in oldfield mice (Peromyscus polionotus). Physiology \& Behavior 80:405-411. DOI: 10.1016/j.physbeh.2003.09.006.

Goymann W. 2012. On the use of non-invasive hormone research in uncontrolled, natural environments: the problem with sex, diet, metabolic rate and the individual: Non-invasive hormone research. Methods in Ecology and Evolution 3:757-765. DOI: 10.1111/j.2041210X.2012.00203.x.

Grant PR. 1976. An 11-year study of small mammal populations at Mont St. Hilaire, Quebec. Canadian Journal of Zoology 54:2156-2173.

Haase CG, Long AK, Gillooly JF. 2016. Energetics of stress: linking plasma cortisol levels to metabolic rate in mammals. Biology Letters 12:20150867. DOI: 10.1098/rsbl.2015.0867.

Harland RM, Blancher PJ, Millar JS. 1979. Demography of a population of Peromyscus leucopus. Candian Journal of Zoology 57: 323-328.

Harper JM, Austad SN. 2000. Fecal Glucocorticoids: A Noninvasive Method of Measuring Adrenal Activity in Wild and Captive Rodents. Physiological and Biochemical Zoology: Ecological and Evolutionary Approaches 73:12-22. DOI: 10.1086/316721. 
736

737

738

739

740

741

742

743

744

745

746

747

748

749

750

751

752

753

754

755

756

757

758

759

760

761

762

763

764

765

766

767

768

769

770

771

772

773

Harper JM, Austad SN. 2001. Effect of Capture and Season on Fecal Glucocorticoid Levels in Deer Mice (Peromyscus maniculatus) and Red-Backed Voles (Clethrionomys gapperi). General and Comparative Endocrinology 123:337-344. DOI: 10.1006/gcen.2001.7682.

Harper GA, Rutherford M. 2016. Home range and population density of black rats (Rattus rattus) on a seabird island: a case for a marine subsidised effect? New Zealand Journal of Ecology 40:219.

Hayssen V, Harper JM, DeFina R. 2002. Fecal corticosteroids in agouti and non-agouti deer mice (Peromyscus maniculatus). Comparative Biochemistry and Physiology Part A: Molecular \& Integrative Physiology 132:439-446.

Heimbürge S, Kanitz E, Otten W. 2019. The use of hair cortisol for the assessment of stress in animals. General and Comparative Endocrinology 270:10-17. DOI: 10.1016/j.ygcen.2018.09.016.

Herman TB, Scott FW. 1984. An unusual decline in abundance of Peromyscus maniculatus in Nova Scotia. Canadian journal of zoology 62:175-178.

Holding ML, Frazier JA, Dorr SW, Pollock NB, Muelleman PJ, Branske A, Henningsen SN, Eikenaar C, Escallón C, Montgomery CE, Moore IT, Taylor EN. 2014. Wet- and Dry-Season Steroid Hormone Profiles and Stress Reactivity of an Insular Dwarf Snake, the Hog Island Boa ( Boa constrictor imperator ). Physiological and Biochemical Zoology 87:363-373. DOI: 10.1086/675938.

Injaian AS, Gonzalez-Gomez PL, Taff CC, Bird AK, Ziur AD, Patricelli GL, Haussmann MF, Wingfield JC. 2019. Traffic noise exposure alters nestling physiology and telomere attrition through direct, but not maternal, effects in a free-living bird. General and Comparative Endocrinology 276: 14-21. DOI: 10.1016/j.ygcen.2019.02.017

Isaac JL. 2005. Potential causes and life-history consequences of sexual size dimorphism in mammals. Mammal Review 35:101-115. DOI: 10.1111/j.1365-2907.2005.00045.x.

Kaufmann JH. 1982. Raccoon and allies. In: Chapman JA, Feldhamer GA, eds. Wild Mammals of North America. Baltimore, Maryland: The Johns Hopkins University Press, 567-585.

Keckeis K, Lepschy M, Schöpper H, Moser L, Troxler J, Palme R. 2012. Hair cortisol: a parameter of chronic stress? Insights from a radiometabolism study in guinea pigs. Journal of Comparative Physiology B 182:985-996. DOI: 10.1007/s00360-012-0674-7.

Keeney DS, Jenkins CM, Waterman MR. 1992. Developmentally Regulated Expression of Adrenal 17 $\alpha$-Hydroxylase Cytochrome P450 in the Mouse Embryo. Endocrinology 132: 4872-4879.

Kitaysky AS, Wingfield JC, Piatt JF. 1999. Dynamics of food availability, body condition and physiological stress response in breeding Black-legged Kittiwakes. Functional Ecology 13:577-584. DOI: 10.1046/j.1365-2435.1999.00352.x.

Kuhn KM, Gienger CM, Tracy CR. 2016. Small Mammals of Pyramid Lake and Anaho Island (Nevada). The Southwestern Naturalist 61:40-44. 
774 Kuznetsova A, Brockhoff PB, Christensen RHB. 2016. lmerTest: Tests in Linear Mixed

775 Effects Models.

776 Landry P-A, Lapointe F-J. 2001. Within-population craniometric variability of insular

777

778

779

780

781

782

783

784

785

786

787

788

789

790

791

792

793

794

795

796

797

798

799

800

801

802

803

804

805

806

807

808

809

810 populations of deer mice, Peromyscus maniculatus, elucidated by landscape configuration. Oikos 95:136-146.

Lomolino MV. 1982. Species-Area and Species-Distance Relatonships of Terrestrial Mammals in the Thousand Islands Region. Oecologia 54: 72-75.

Lomolino MV. 1984. Immigrant Selection, Predation, and the Distributions of Microtus pennsylvanicus and Blarina brevicauda on Islands. The American Naturalist 123:468-483.

Lomolino MV. 1989. Bioenergetics of cross-ice movements by Microtus pennsylvanicus, Peromyscus leucopus and Blarina brevicauda. Ecography 12:213-218. DOI: 10.1111/j.1600-0587.1989.tb00840.x.

Lomolino MV. 2005. Body size evolution in insular vertebrates: generality of the island rule. Journal of Biogeography 32:1683-1699. DOI: 10.1111/j.1365-2699.2005.01314.x.

Lomolino MV, Sax DF, Palombo MR, van der Geer AA. 2012. Of mice and mammoths: evaluations of causal explanations for body size evolution in insular mammals: Body size evolution in insular mammals. Journal of Biogeography 39:842-854. DOI:

10.1111/j.1365-2699.2011.02656.x.

Losos JB, Ricklefs RE. 2009. Adaptation and diversification on islands. Nature 457:830-836. DOI: $10.1038 /$ nature 07893 .

MacArthur RH, Wilson EO. 1967. Theory of Island Biogeography. (MPB-1). Princeton University Press.

Macbeth BJ, Cattet MRL, Stenhouse GB, Gibeau ML, Janz DM. 2010. Hair cortisol concentration as a noninvasive measure of long-term stress in free-ranging grizzly bears (Ursus arctos): considerations with implications for other wildlife. Canadian Journal of Zoology 88:935-949. DOI: 10.1139/Z10-057.

Manson RH, Stiles EW. 1998. Links between Microhabitat Preferences and Seed Predation by Small Mammals in Old Fields. Oikos 82:37-50. DOI: 10.2307/3546915.

Martin JGA, Réale D. 2008. Animal temperament and human disturbance: Implications for the response of wildlife to tourism. Behavioural Processes 77:66-72. DOI: 10.1016/j.beproc.2007.06.004.

Mastromonaco GF, Gunn K, McCurdy-Adams H, Edwards DB, Schulte-Hostedde AI. 2014. Validation and use of hair cortisol as a measure of chronic stress in eastern chipmunks (Tamias striatus). Conservation Physiology 2:cou055.

Matson KD, Mauck RA, Lynn SE, Irene Tieleman B. 2014. Island Life Shapes the Physiology and Life History of Eastern Bluebirds ( Sialia sialis )*. Physiological and Biochemical Zoology 87:172-182. DOI: 10.1086/670811. 
811 McEwen BS, Wingfield JC. 2003. The concept of allostasis in biology and biomedicine.

812 Hormones and Behavior 43:2-15. DOI: 10.1016/S0018-506X(02)00024-7.

813 Millar JS, Wille FB. 1979. Breeding by Peromyscus in seasonal environments. Canadian 814 Journal of Zoology 57: 719-727.

815 Müller C, Jenni-Eiermann S, Blondel J, Perret P, Caro SP, Lambrechts MM, Jenni L.

816 2007. Circulating corticosterone levels in breeding blue tits Parus caeruleus differ between

817 island and mainland populations and between habitats. General and Comparative

818 Endocrinology 154:128-136. DOI: 10.1016/j.ygcen.2007.05.031.

819 Nakagawa S, Schielzeth H. 2013. A general and simple method for obtaining $R^{2}$ from

820 generalized linear mixed-effects models. Methods in Ecology and Evolution 4:133-142.

821 DOI: $10.1111 /$ j.2041-210x.2012.00261.x.

822 Nelson L, Clark FW. 1973. Correction for Sprung Traps in Catch/Effort Calculations of

823 Trapping Results. Journal of Mammalogy 54:295-298. DOI: 10.2307/1378903.

824 Novosolov M, Raia P, Meiri S. 2013. The island syndrome in lizards. Global Ecology and

825 Biogeography 22:184-191. DOI: 10.1111/j.1466-8238.2012.00791.x.

826 Novikov E, Moshkin M. 1998. Sexual maturation, adrenocrotical function and population

827 density of red-backed vole, Clethrionomys rutilus (Pall.). Mammalia 62(4):529-540.

828 Nupp TE, Swihart RK. 1996. Effect of forest patch area on population attributes of white-

829 footed mice (Peromyscus leucopus) in fragmented landscapes. Canadian Journal of

830 Zoology 74:467-472. DOI: 10.1139/z96-054.

831 Parker GC, Black A, Rexer-Huber K, Sommer E, Cuthbert RJ. 2016. Low population

832 density and biology of an island population of house mice Mus musculus on South

833 Georgia. Polar Biology 39:1175-1181. DOI: 10.1007/s00300-015-1831-8.

834 Parnell T, Narayan EJ, Nicolson V, Martin-Vegue P, Mucci AI, Hero J-M. 2015.

835 Maximizing the reliability of non-invasive endocrine sampling in the tiger (Panthera

836 tigris): environmental decay and intra-sample variation in faecal glucocorticoid

837 metabolites. Conservation Physiology 3 DOI:10.1093/conphys/cov053.

838 Pierce SS, Vogt FD. 1993. Winter Acclimatization in Peromyscus maniculatus gracilis, P.

839 leucopus noveboracensis, and P. 1. leucopus. Journal of Mammalogy 74:665-677. DOI:

$840 \quad \underline{10.2307 / 1382288}$.

841 Reeder DM, Kramer KM. 2005. Stress in free-ranging mammals: integrating physiology,

842 ecology, and natural history. Journal of Mammalogy 86:225-235.

843 Romero LM. 2002. Seasonal changes in plasma glucocorticoid concentrations in free-living

844 vertebrates. General and comparative endocrinology 128:1-24.

845 Romero LM, Meister CJ, Cyr NE, Kenagy GJ, Wingfield JC. 2007. Seasonal glucocorticoid

846 responses to capture in wild free-living mammals. AJP: Regulatory, Integrative and

847 Comparative Physiology 294:R614-R622. DOI: 10.1152/ajpregu.00752.2007. 
848 Romero LM, Wingfield JC. 2016. Tempests, poxes, predators, and people: stress in wild

849

850

851

852

853

854

855

856

857

858

859

860

861

862

863

864

865

866

867

868

869

870

871

872

873

874

875

876

877

878

879

880

881

882

883 animals and how they cope. Oxford; New York: Oxford University Press.

Sale MG, Arnould JPY. 2013. Inflated population density of island antechinus: a case of allochthonous marine inputs leading to increased food availability? Australian Journal of Zoology 60:343-351. DOI: 10.1071/ZO12073.

Sapolsky RM. 1982. The endocrine stress-response and social status in the wild baboon. Hormones and Behavior 16:279-292. DOI: 10.1016/0018-506X(82)90027-7.

Sapolsky RM, Romero LM, Munck AU. 2000. How Do Glucocorticoids Influence Stress Responses? Integrating Permissive, Suppressive, Stimulatory, and Preparative Actions. Endocrine Reviews 21:55-89. DOI: 10.1210/edrv.21.1.0389.

Schradin C. 2008. Seasonal changes in testosterone and corticosterone levels in four social classes of a desert dwelling sociable rodent. Hormones and Behavior 53:573-579. DOI: 10.1016/j.yhbeh.2008.01.003.

Schulte-Hostedde AI, Millar JS, Hickling GJ. 2001. Sexual dimorphism in body composition of small mammals. Canadian Journal of Zoology 79:1016-1020.

Scorrano F, Carrasco J, Pastor-Ciurana J, Belda X, Rami-Bastante A, Bacci ML, Armario A. 2015. Validation of the long-term assessment of hypothalamic-pituitary-adrenal activity in rats using hair corticosterone as a biomarker. The FASEB Journal 29:859-867. DOI: 10.1096/fj.14-254474.

Sharpley CF, Kauter KG, McFarlane JR. 2009. An initial exploration of in vivo hair cortisol responses to a brief pain stressor: latency, localization and independence effects. Physiological Research 58:757-761.

Sheriff MJ, Dantzer B, Delehanty B, Palme R, Boonstra R. 2011. Measuring stress in wildlife: techniques for quantifying glucocorticoids. Oecologia 166:869-887. DOI: 10.1007/s00442-011-1943-y.

Sheriff MJ, Krebs CJ, Boonstra R. 2011. From process to pattern: how fluctuating predation risk impacts the stress axis of snowshoe hares during the 10-year cycle. Oecologia 166:593-605. DOI: 10.1007/s00442-011-1907-2.

Smith JE, Monclús R, Wantuck D, Florant GL, Blumstein DT. 2012. Fecal glucocorticoid metabolites in wild yellow-bellied marmots: Experimental validation, individual differences and ecological correlates. General and Comparative Endocrinology 178:417426. DOI: 10.1016/j.ygcen.2012.06.015.

Spencer PBS, Sandover S, Nihill K, Wale CH, How RA, Schmitt LH. 2017. Living in isolation: ecological, demographic and genetic patterns in northern Australia's top marsupial predator on Koolan Island. Australian Mammalogy 39:17-27. DOI: 10.1071/AM16004. 
884 Stapp P, Polis GA. 2003. Marine resources subsidize insular rodent populations in the Gulf of

885

886

887

888

889

890

891

892

893

894

895

896

897

898

899

900

901

902

903

904

905

906

907

908

909

910

911

912

913

914

915

916

917

918

919

920

921

922

California, Mexico. Oecologia 134:496-504. DOI: 10.1007/s00442-002-1146-7.

Stewart ND, Reilly A, Gilman C, Mastromonaco GF, Burness G. 2018. Evidence of degradation of hair corticosterone in museum specimens. General and Comparative Endocrinology 268:128-133. DOI: 10.1016/j.ygcen.2018.08.011.

Stothart MR, Bobbie CB, Schulte-Hostedde AI, Boonstra R, Palme R, Mykytczuk NCS, Newman AEM. 2016. Stress and the microbiome: linking glucocorticoids to bacterial community dynamics in wild red squirrels. Biology Letters 12: 20150875. DOI: $10.1098 /$ rsbl.2015.0875

Tabacaru CA, Millar JS, Longstaffe FJ. 2011. Seasonal Moulting in Deer Mice (Peromyscus maniculatus) in the Rocky Mountains, Alberta. The Canadian Field-Naturalist 125:126131. DOI: $10.22621 / \mathrm{cfn} . \mathrm{v} 125 \mathrm{i} 2.1195$.

Tamarin RH, Sheridan M. 1987. Behavior-Genetic Mechanisms of Population Regulation in Microtine Rodents. Integrative and Comparative Biology 27:921-927. DOI: $10.1093 / \mathrm{icb} / 27.3 .921$.

Trivers R. 1972. Parental investment and sexual selection. In: Campbell B, ed. Sexual Selection and the Descent of Man, 1871-1971. Chicago: Aldine, 136-179.

Touma C, Sachser N, Mostl, E, Palme, R. 2003. Effects of sex and time of day on metabolism and excretion of corticosterone in urine and feces of mice. General and Comparative Endocrinology 130: 267-278. DOI:10.1016/S0016-6480(02)00620-2.

United States Geological Survey (USGS). 2016. USGS National Hydrography Dataset. Accessed September 2016, currently available from: https://www.sciencebase.gov/catalog/item/5a58a491e4b00b291cd687e1.

Vandegrift KJ, Raffel TR, Hudson PJ. 2008. Parasites Prevent Summer Breeding in WhiteFooted Mice, Peromyscus Leucopus. Ecology 89:2251-2258. DOI: 10.1890/07-1935.1.

Van Valen L. 1973. A new evolutionary law. Evolutionary Theory 1:1-30.

Vucetich LM, Vucetich JA, Joshi CP, Waite TA, Peterson RO. 2001. Genetic (RAPD) diversity in Peromyscus maniculatus populations in a naturally fragmented landscape. Molecular Ecology 10:35-40. DOI: 10.1046/j.1365-294X.2001.01173.x.

Walker BG, Wingfield JC, Boersma PD. 2005. Age and Food Deprivation Affects Expression of the Glucocorticosteroid Stress Response in Magellanic Penguin (Spheniscus magellanicus) Chicks. Physiological and Biochemical Zoology 78:78-89. DOI: $10.1086 / 422769$.

Warren BH, Simberloff D, Ricklefs RE, Aguilée R, Condamine FL, Gravel D, Morlon H, Mouquet N, Rosindell J, Casquet J, Conti E, Cornuault J, Fernández-Palacios JM, Hengl T, Norder SJ, Rijsdijk KF, Sanmartín I, Strasberg D, Triantis KA, Valente LM, Whittaker RJ, Gillespie RG, Emerson BC, Thébaud C. 2015. Islands as model systems in ecology and evolution: prospects fifty years after MacArthur-Wilson. Ecology Letters 18:200-217. DOI: 10.1111/ele.12398.

Peer) reviewing PDF | (2019:06:38691:2:0:NEW 10 Jan 2020) 
923 Waterhouse MD, Sjodin B, Ray C, Erb L, Wilkening J, Russello MA. 2017. Individual-based

924 analysis of hair corticosterone reveals factors influencing chronic stress in the American 925 pika. Ecology and Evolution. DOI: 10.1002/ece3.3009.

926

927

928

929

930

931

932

933

934

935

936

937

938

939

940

941

942

943

944

945
Werden L, Barker IK, Bowman J, Gonzales EK, Leighton PA, Lindsay LR, Jardine CM. 2014. Geography, Deer, and Host Biodiversity Shape the Pattern of Lyme Disease Emergence in the Thousand Islands Archipelago of Ontario, Canada. PLoS ONE 9:e85640. DOI: 10.1371/journal.pone.0085640.

Wilkening JL, Ray C. 2016. Characterizing predictors of survival in the American pika (Ochotona princeps). Journal of Mammalogy 97: 1366-1375. DOI:10.1093/jmammal/gyw097

Wingfield JC, Smith JP, Farner DS. 1982. Endocrine Responses of White-Crowned Sparrows to Environmental Stress. The Condor: Ornithological Applications 84:399-409. DOI: $10.2307 / 1367443$.

Wolff JO. 1984. The effects of density, food, and interspecific interference on home range size in Peromyscus leucopus and Peromyscus maniculatus. Canadian Journal of Zoology 63:2657-2662.

Wolff JO. 1993. Why Are Female Small Mammals Territorial? Oikos 68:364-370. DOI: $\underline{10.2307 / 3544853 .}$.

Young AJ, Carlson AA, Monfort SL, Russel AF, Bennet NC, Clutton-Brock T. 2006. Stress and the suppression of subordinate reproduction in cooperatively breeding meerkats. Proceedings of the National Academy of Sciences 103(32):12005-12010. 


\section{Table $\mathbf{1}$ (on next page)}

Factors predicting relative abundance of white-footed mice captured over two years, for two separate models (island- mainland comparison, and among-islands comparison).

Linear-mixed effects models were used for analysis (random effect: sampling site, nested within habitat type) of variation between island and mainland sites, and among islands in response to geographic variables. Marginal (M) and conditional (C) pseudo $R^{2}\left(R_{\text {GLMM }}^{2}\right)$ values are provided. Models were reduced by removing all non-significant two-way interactions. 
1 Table 1. Factors predicting relative abundance of white-footed mice captured over two

2 years, for two separate models (island- mainland comparison, and among-islands

3 comparison).

\begin{tabular}{llllllll}
\hline Dataset & Fixed effects & $\beta$ & se & df & $t$ & $p$ & $\begin{array}{l}R_{\text {GLMM }}^{2} \\
(\mathrm{M}),(\mathrm{C})\end{array}$ \\
\hline $\begin{array}{l}\text { Island and } \\
\text { mainland } \\
\text { mice }\end{array}$ & Intercept & 16640 & 4.801 & 34 & 3.47 & 0.001 & 0.23, \\
& Habitat (mainland) & 2.60 & 5.90 & 13 & 0.44 & 0.667 & 0.68 \\
& Year (2016) & -8.88 & 3.27 & 22 & -2.72 & $\mathbf{0 . 0 1 2}$ & \\
& Season (summer) & 7.16 & 3.15 & 22 & 2.27 & $\mathbf{0 . 0 3 3}$ & \\
& & & & & & & \\
\hline
\end{tabular}

$\begin{array}{llllllll}\begin{array}{l}\text { Island } \\ \text { mice }\end{array} & \text { Intercept } & 40.00 & 32.05 & 8 & 1.248 & 0.244 & 0.27, \\ & \text { Year (2016) } & -11.86 & 4.08 & 14 & -2.91 & \mathbf{0 . 0 1 1} & 0.76 \\ & \text { Season (summer) } & 7.48 & 4.05 & 14 & 1.85 & 0.085 & \\ & & & & & & & \\ & \log _{10} \text { (Area) } & 2.72 & 5.03 & 7 & 0.54 & 0.603 & \\ & & & & & & \\ & \log _{10} \text { (Distance) } & -8.86 & 11.00 & 8 & -0.81 & 0.442\end{array}$

4 Linear-mixed effects models were used for analysis (random effect: sampling site, nested within

5 habitat type) of variation between island and mainland sites, and among islands in response to

6 geographic variables. Marginal (M) and conditional (C) pseudo $R^{2}\left(R^{2}{ }_{\text {GLMM }}\right)$ values are

7 provided. Models were reduced by removing all non-significant two-way interactions. 


\section{Table 2 (on next page)}

Factors predicting body mass of white-footed mice during summer (July-August) in two years, for two separate models (island-mainland comparison, and among-islands comparison).

Linear-mixed effects models were used for analysis (random effect: sampling site, nested within habitat type). Marginal (M) and conditional (C) pseudo $R^{2}\left(R_{\text {GLMM }}^{2}\right)$ values are provided. Models were reduced by removing all non-significant two-way interactions. 
1 Table 2. Factors predicting body mass of white-footed mice during summer (July-August)

2 in two years, for two separate models (island-mainland comparison, and among-islands

3 comparison).

\begin{tabular}{|c|c|c|c|c|c|c|c|}
\hline Dataset & Fixed effects & $\beta$ & se & $\mathrm{df}$ & $t$ & $p$ & $R_{\mathrm{GLM}}^{2}$ \\
\hline \multirow{4}{*}{$\begin{array}{l}\text { Island and } \\
\text { mainland } \\
\text { mice }\end{array}$} & Intercept & 2.985 & 0.02 & 17 & 133.04 & $<0.0001$ & \multirow[t]{4}{*}{$\begin{array}{l}0.02, \\
0.04\end{array}$} \\
\hline & Habitat (Mainland) & -0.008 & 0.03 & 9 & -0.25 & 0.804 & \\
\hline & Sex (Male) & 0.052 & 0.02 & 295 & 2.34 & 0.020 & \\
\hline & Year (2016) & -0.004 & 0.02 & 292 & -0.16 & 0.875 & \\
\hline \multirow{5}{*}{$\begin{array}{l}\text { Island } \\
\text { mice }\end{array}$} & Intercept & 2.826 & 0.14 & 8 & 19.6 & $<0.0001$ & \multirow{5}{*}{$\begin{array}{l}0.04 \\
0.04\end{array}$} \\
\hline & Sex (Male) & 0.061 & 0.03 & 203 & 2.37 & 0.019 & \\
\hline & $\log _{10}$ (Area) & 0.014 & 0.02 & 5 & 0.76 & 0.476 & \\
\hline & $\log _{10}($ Distance $)$ & 0.048 & 0.05 & 8 & 0.91 & 0.385 & \\
\hline & Year (2016) & -0.017 & 0.03 & 203 & -0.61 & 0.545 & \\
\hline
\end{tabular}

4 Linear-mixed effects models were used for analysis (random effect: sampling site, nested within

5 habitat type). Marginal (M) and conditional (C) pseudo $R^{2}\left(R^{2}{ }_{\mathrm{GLMM}}\right)$ values are provided. Models

6 were reduced by removing all non-significant two-way interactions. 


\section{Table 3 (on next page)}

Factors predicting hair corticosterone of white-footed mice during summer (July-August) in two years, for two separate models (island- mainland comparison, and among-islands comparison).

Linear-mixed effects models were used for analysis (random effect: sampling site, nested within habitat type). Marginal (M) and conditional (C) pseudo $R^{2}\left(R_{\text {GLMM }}^{2}\right)$ values are provided. Models were reduced by removing all non-significant two-way interactions. 
1 Table 3. Factors predicting hair corticosterone of white-footed mice during summer (July-

2 August) in two years, for two separate models (island- mainland comparison, and among-

3 islands comparison).

\begin{tabular}{|c|c|c|c|c|c|c|c|}
\hline Dataset & Fixed effects & $\beta$ & se & $\mathrm{df}$ & $t$ & $p$ & $R_{\mathrm{GLN}}^{2}$ \\
\hline \multirow{6}{*}{$\begin{array}{l}\text { Island and } \\
\text { mainland } \\
\text { mice }\end{array}$} & Intercept & 2.812 & 0.539 & 253 & 5.216 & $<0.0001$ & $\begin{array}{l}0.05 \text {, } \\
0.14\end{array}$ \\
\hline & Habitat (mainland) & -0.104 & 0.120 & 10 & -0.86 & 0.4080 & \\
\hline & CPUE (Corrected) & -0.004 & 0.004 & 20 & -0.89 & 0.3837 & \\
\hline & Sex (Male) & -0.003 & 0.064 & 261 & -0.05 & 0.9611 & \\
\hline & Year (2016) & 0.051 & 0.078 & 104 & 0.65 & 0.5159 & \\
\hline & Ln Body Mass & 0.568 & 0.172 & 261 & 3.31 & 0.0011 & \\
\hline \multirow{7}{*}{$\begin{array}{l}\text { Island } \\
\text { mice }\end{array}$} & Intercept & 2.824 & 0.923 & 15 & 3.06 & 0.0075 & 0.07, \\
\hline & Sex (Male) & -0.003 & 0.077 & 179 & -0.04 & 0.9713 & \\
\hline & CPUE (Corrected) & -0.002 & 0.005 & 6 & -0.45 & 0.6675 & \\
\hline & $\log _{10}$ Isl. Area & 0.076 & 0.097 & 3 & 0.79 & 0.4807 & \\
\hline & $\log _{10}$ Isl. Distance & -0.134 & 0.243 & 4 & -0.55 & 0.6092 & \\
\hline & Year (2016) & 0.077 & 0.110 & 19 & 0.70 & 0.4934 & \\
\hline & Ln Body Mass & 0.631 & 0.211 & 179 & 3.00 & 0.0031 & \\
\hline
\end{tabular}

4 Linear-mixed effects models were used for analysis (random effect: sampling site, nested within

5 habitat type). Marginal (M) and conditional (C) pseudo $R^{2}\left(R^{2}{ }_{\mathrm{GLMM}}\right)$ values are provided. Models

6 were reduced by removing all non-significant two-way interactions. 


\section{Table 4 (on next page)}

Factors predicting fecal corticosterone metabolites of white-footed mice during summer (July-August) in two years, for two separate models (island- mainland comparison, and among-islands comparison).

Linear-mixed effects models were used for analysis (random effect: sampling site, nested within habitat type). Marginal (M) and conditional (C) pseudo $R^{2}\left(R_{\text {GLMM }}^{2}\right)$ values are provided. Both models were reduced by removing all non-significant two-way interactions, relative abundance, and In-transformed body mass. 
1 Table 4. Factors predicting fecal corticosterone metabolites of white-footed mice during

2 summer (July-August) in two years, for two separate models (island- mainland

3 comparison, and among-islands comparison).

\begin{tabular}{|c|c|c|c|c|c|c|c|}
\hline Dataset & Fixed effect & $\beta$ & se & $\mathrm{df}$ & $t$ & $p$ & $\begin{array}{l}R^{2}{ }_{\mathrm{GLMM}} \\
\text { (M). (C) }\end{array}$ \\
\hline \multirow{4}{*}{$\begin{array}{l}\text { Island and } \\
\text { mainland } \\
\text { mice }\end{array}$} & Intercept & 5.695 & 0.779 & 12 & 73.13 & $<0.0001$ & $0.25,0.31$ \\
\hline & Habitat (Mainland) & 0.022 & 0.12 & 10 & 0.18 & 0.8578 & \\
\hline & Sex (Male) & -0.136 & 0.07 & 201 & -1.98 & 0.0492 & \\
\hline & Year (2016) & 0.620 & 0.07 & 204 & 8.27 & $<0.0001$ & \\
\hline \multirow[t]{5}{*}{ Island mice } & Intercept & 5.960 & 0.489 & 7 & 12.18 & $<0.0001$ & $0.21,0.25$ \\
\hline & Sex (Male) & -0.108 & 0.07 & 153 & -1.52 & 0.1320 & \\
\hline & Year (2016) & 0.533 & 0.08 & 154 & 6.52 & $<0.0001$ & \\
\hline & $\log _{10}$ Isl. Area & -0.002 & 0.03 & 4 & -0.07 & 0.9440 & \\
\hline & $\log _{10}$ Is1. Distance & -0.039 & 0.08 & 6 & -0.50 & 0.6320 & \\
\hline
\end{tabular}

4 Linear-mixed effects models were used for analysis (random effect: sampling site, nested within

5 habitat type). Marginal (M) and conditional (C) pseudo $R^{2}\left(R^{2}{ }_{\mathrm{GLMM}}\right)$ values are provided. Both

6 models were reduced by removing all non-significant two-way interactions, relative abundance,

7 and $\ln$-transformed body mass. 


\section{Table 5 (on next page)}

Factors predicting seasonal variation in hair corticosterone of white-footed mice captured in spring (May-June) and summer (July-August) 2016.

A linear-mixed effects model was used for analysis (random effect: sampling site, nested within habitat type). Marginal (M) and conditional (C) pseudo $R^{2}\left(R_{\text {GLMM }}^{2}\right)$ values are provided. The results from the full model are presented. 
2 Table 5. Factors predicting seasonal variation in hair corticosterone of white-footed mice

3 captured in spring (May-June) and summer (July-August) 2016.

\begin{tabular}{lllllll}
\hline Fixed effect & $\beta$ & se & df & $t$ & $p$ & $\begin{array}{l}R_{\text {GLMM }}^{2} \\
\text { (M), (C) }\end{array}$ \\
\hline Intercept & 1.258 & 0.596 & 138 & 2.11 & 0.037 & $0.22,0.35$ \\
Sex (Male) & 0.553 & 0.117 & 136 & 4.73 & $<\mathbf{0 . 0 0 0 1}$ & \\
Season (Summer) & 0.472 & 0.119 & 137 & 3.96 & $\mathbf{0 . 0 0 0 1}$ & \\
Ln Body Mass & 0.891 & 0.186 & 136 & 4.78 & $<\mathbf{0 . 0 0 0 1}$ & \\
Sex x Season & -0.496 & 0.145 & 135 & -3.41 & $\mathbf{0 . 0 0 0 9}$ &
\end{tabular}

4 A linear-mixed effects model was used for analysis (random effect: sampling site, nested within

5 habitat type). Marginal (M) and conditional (C) pseudo $R^{2}\left(R^{2}{ }_{\mathrm{GLMM}}\right)$ values are provided. The 6 results from the full model are presented. 


\section{Table 6(on next page)}

Factors predicting seasonal variation in fecal corticosterone metabolites of white-footed mice captured during spring (May-June) and summer (July-August) 2016.

A linear-mixed effects model was used for analysis (random effect: sampling site, nested within habitat type). Marginal (M) and conditional (C) pseudo $R^{2}\left(R_{\text {GLMM }}^{2}\right)$ values are provided. The model was reduced by removing all non-significant two-way interactions and Intransformed body mass. 
2 Table 6. Factors predicting seasonal variation in fecal corticosterone metabolites of white-

3 footed mice captured during spring (May-June) and summer (July-August) 2016.

\begin{tabular}{lllllll}
\hline Fixed effect & $\beta$ & se & df & $t$ & $p$ & $\begin{array}{l}R_{\text {GLMM }}^{2} \\
\text { (M). (C) }\end{array}$ \\
\hline Intercept & 5.90 & 0.09 & 39 & 64.75 & $<0.0001$ & $0.30,0.44$ \\
Sex (Male) & 0.12 & 0.08 & 62 & 1.40 & 0.168 & \\
Season (Summer) & 0.45 & 0.09 & 67 & 5.13 & $<\mathbf{0 . 0 0 0 1}$ &
\end{tabular}

4 A linear-mixed effects model was used for analysis (random effect: sampling site, nested within

5 habitat type). Marginal (M) and conditional (C) pseudo $R^{2}\left(R^{2}{ }_{\text {GLMM }}\right)$ values are provided. The

6 model was reduced by removing all non-significant two-way interactions and ln-transformed

7 body mass. 


\section{Figure 1}

Trapping locations of white-footed mice (Peromyscus leucopus) in Thousand Islands National Park, Ontario, Canada (USGS, 2016).

Islands on which trapping occurred are shaded in dark grey. Abbreviations: Al - Aubrey

Island, BI - Beau Rivage Island, CE - Constance Island, Cl - Camelot Island, EP - Escot

Property, GA - Georgina Island, GI - Grenadier Island, HI - Hill Island, JC1 - Jones Creek 1, JC2

- Jones Creek 2, LB - Landon Bay, LI - Lindsay Island, MD - McDonald Island, MI - Mermaid Island, MT - Mallorytown, and TI - Thwartway Island. 


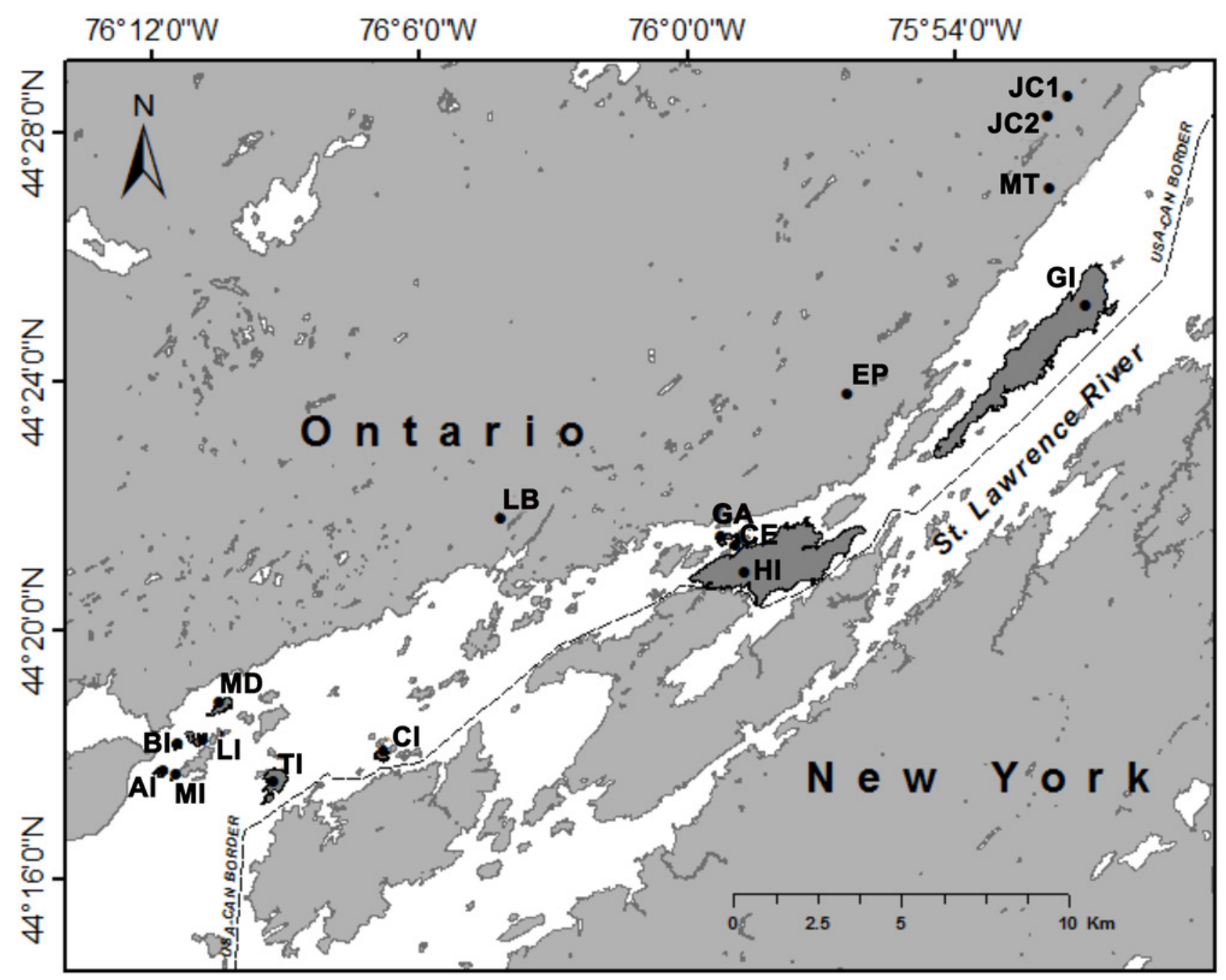




\section{Figure 2}

Correlation between years in abundance of white-footed mouse (Peromyscus leucopus) at multiple trapping locations.

All trapping occurred in Thousand Islands National Park, Canada. The solid black line represents the linear relationship in abundance between the two years and the dashed line represents the predicted line if abundances were equal between years. Points that fall on the dotted line represent sites where abundance was nearly equal for white-footed mice between the two years. Abundance was measured in catch-per-unit-effort (CPUE, captures per 100 trap nights), which was corrected for tripped traps. Abbreviations represent individual sampling locations and correspond with those in Figure 1. 


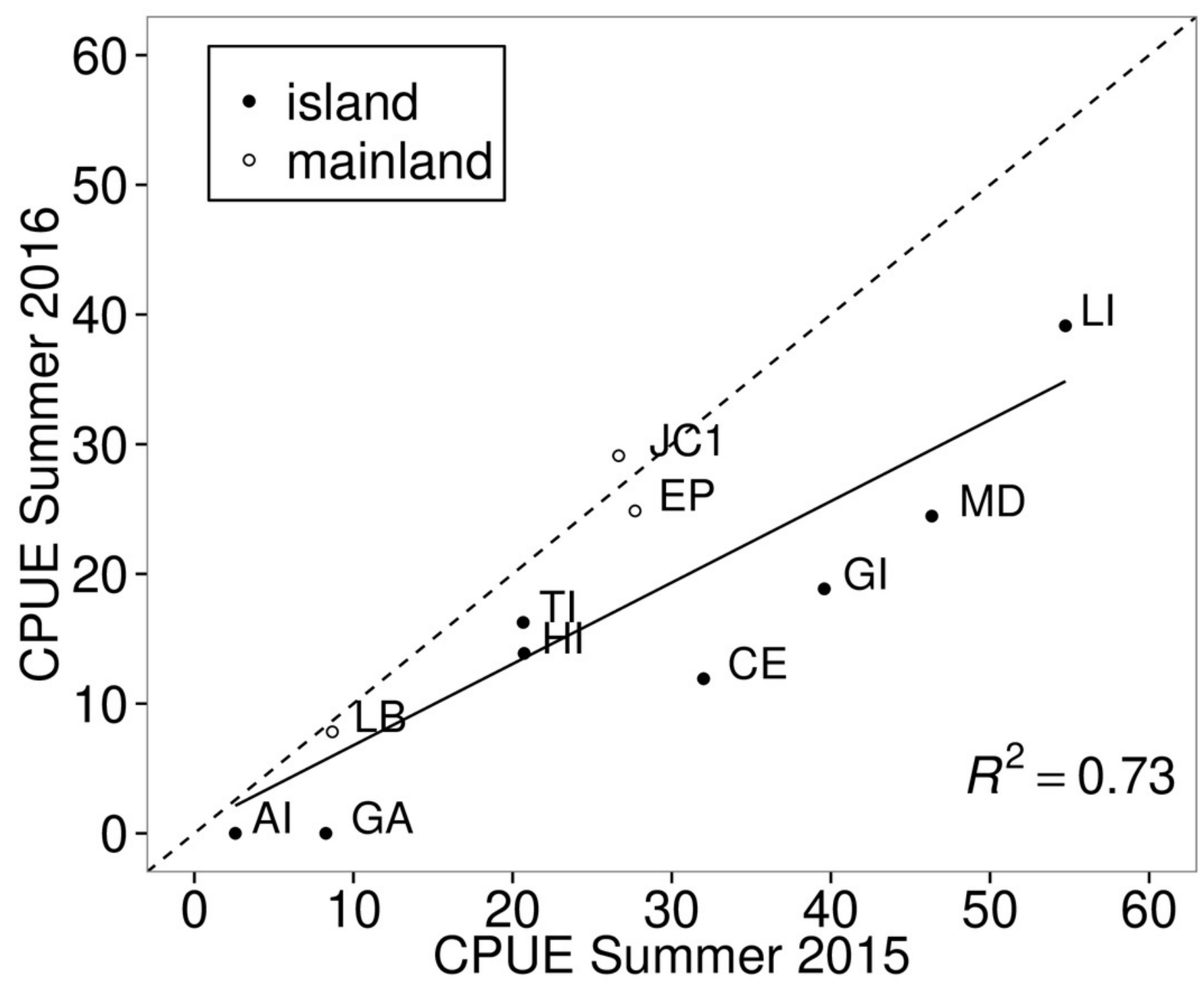


Figure 3

Body mass (A), hair corticosterone (B), and fecal corticosterone metabolites (C) of white-footed mice captured during the summer (July-August) in two consecutive years.

Body mass was measured in grams, and both measures of CORT were measured in $\mathrm{ng} / \mathrm{g}$. All response variables were In-transformed. 

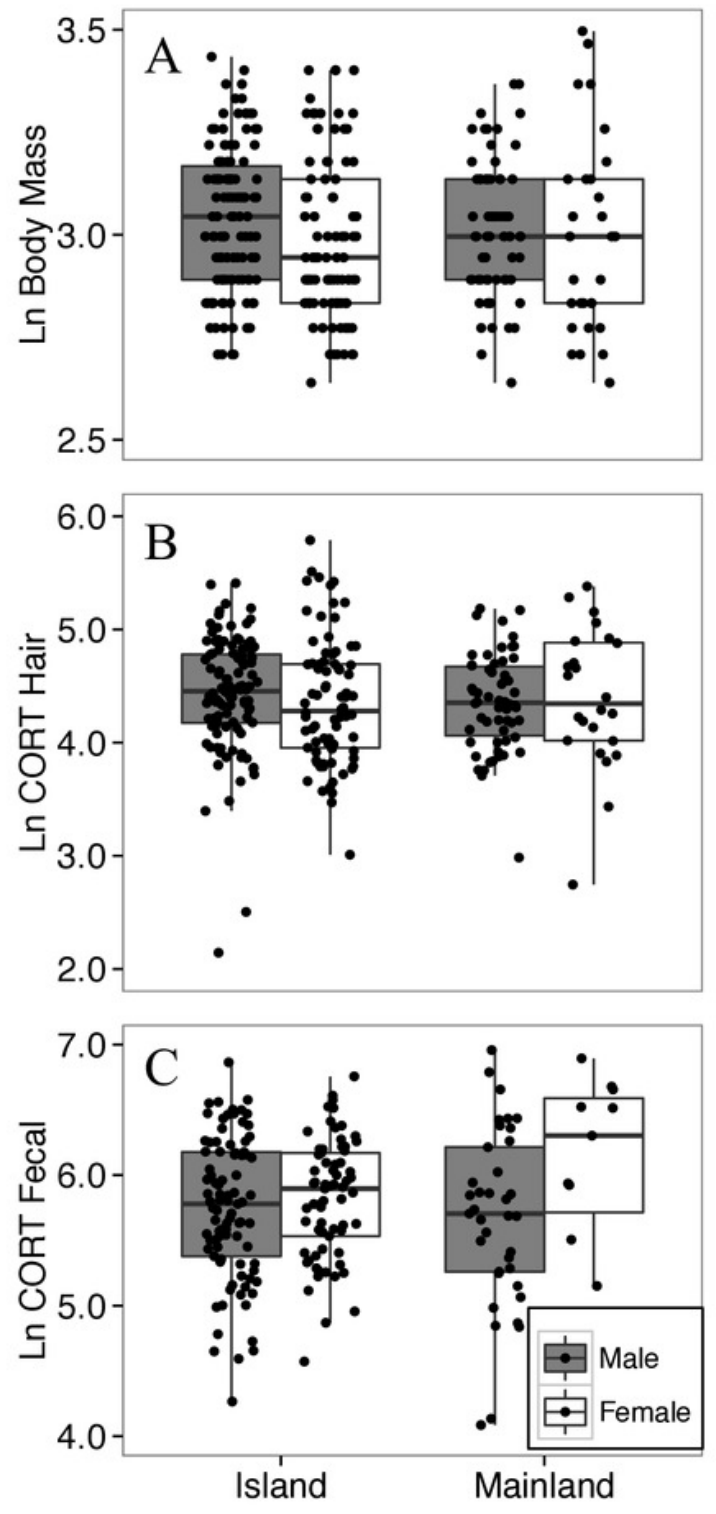


\section{Figure 4}

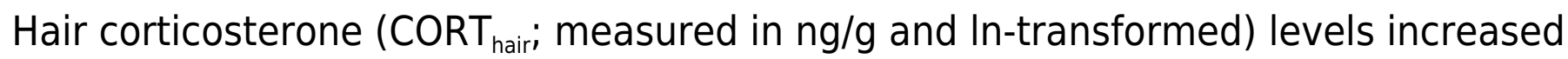
with body mass in white food mice captured over two years in the Thousand Islands National Park, Canada.

The solid line shows a simple regression line; however, the relationship was tested within a linear mixed effects model. Body mass was measured in grams, and $\mathrm{CORT}_{\text {hair }}$ was measured in $\mathrm{ng} / \mathrm{g}$. Both measures were In-transformed. 


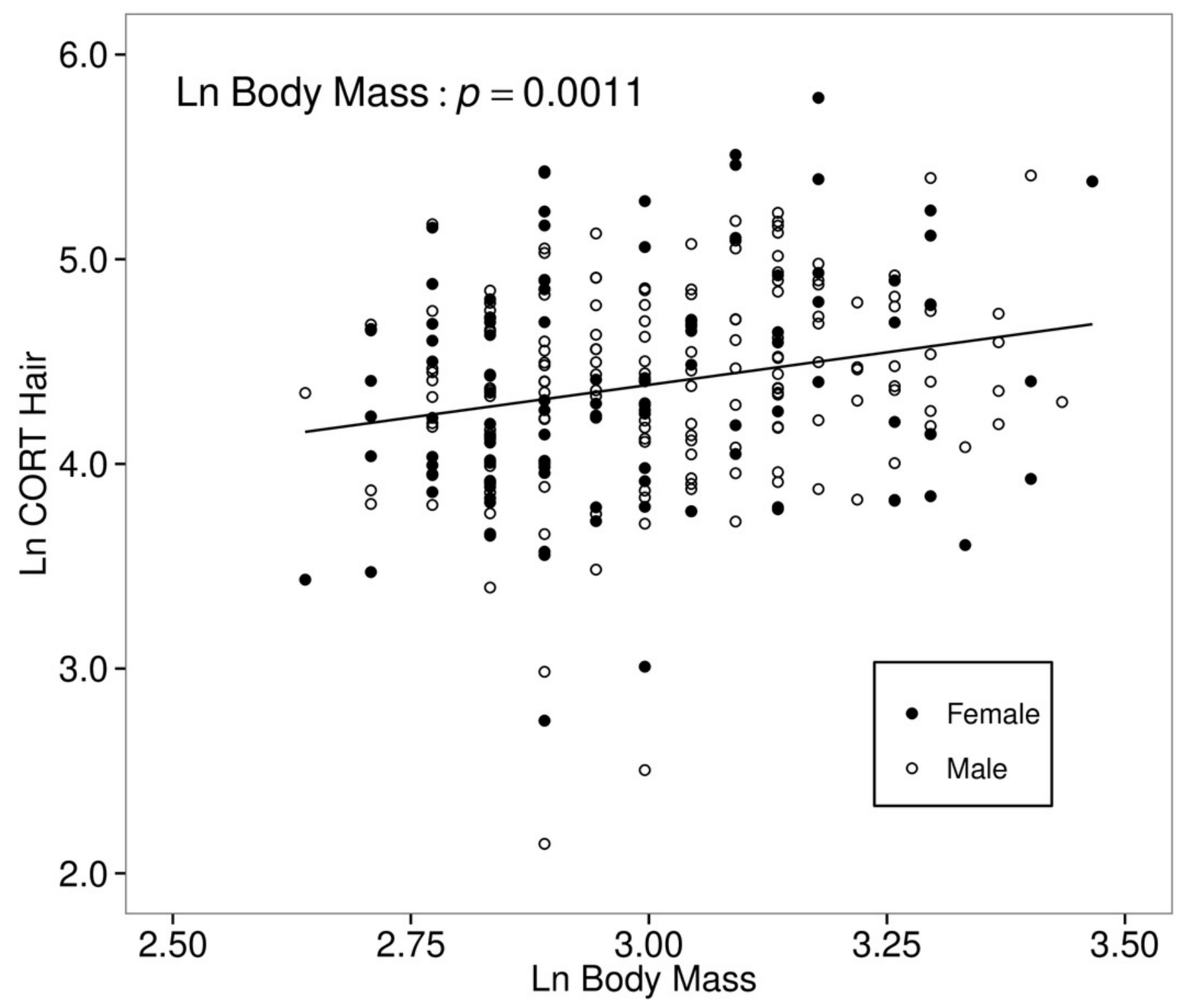




\section{Figure 5}

Seasonal variation in (A) hair corticosterone (CORT hair), and (B) fecal corticosterone metabolites (CORT fecal $_{\text {) }}$ from white-footed mice captured in spring and summer, 2016.

Females had lower hair corticosterone levels in the spring (May-June) than in the summer (July-August) (sex*season interaction; $p<0.0009$; A), while both sexes had lower fecal corticosterone metabolites in spring than summer $(p<0.0001$; B). Both CORT measures were quantified in $\mathrm{ng} / \mathrm{g}$ and In-transformed. 

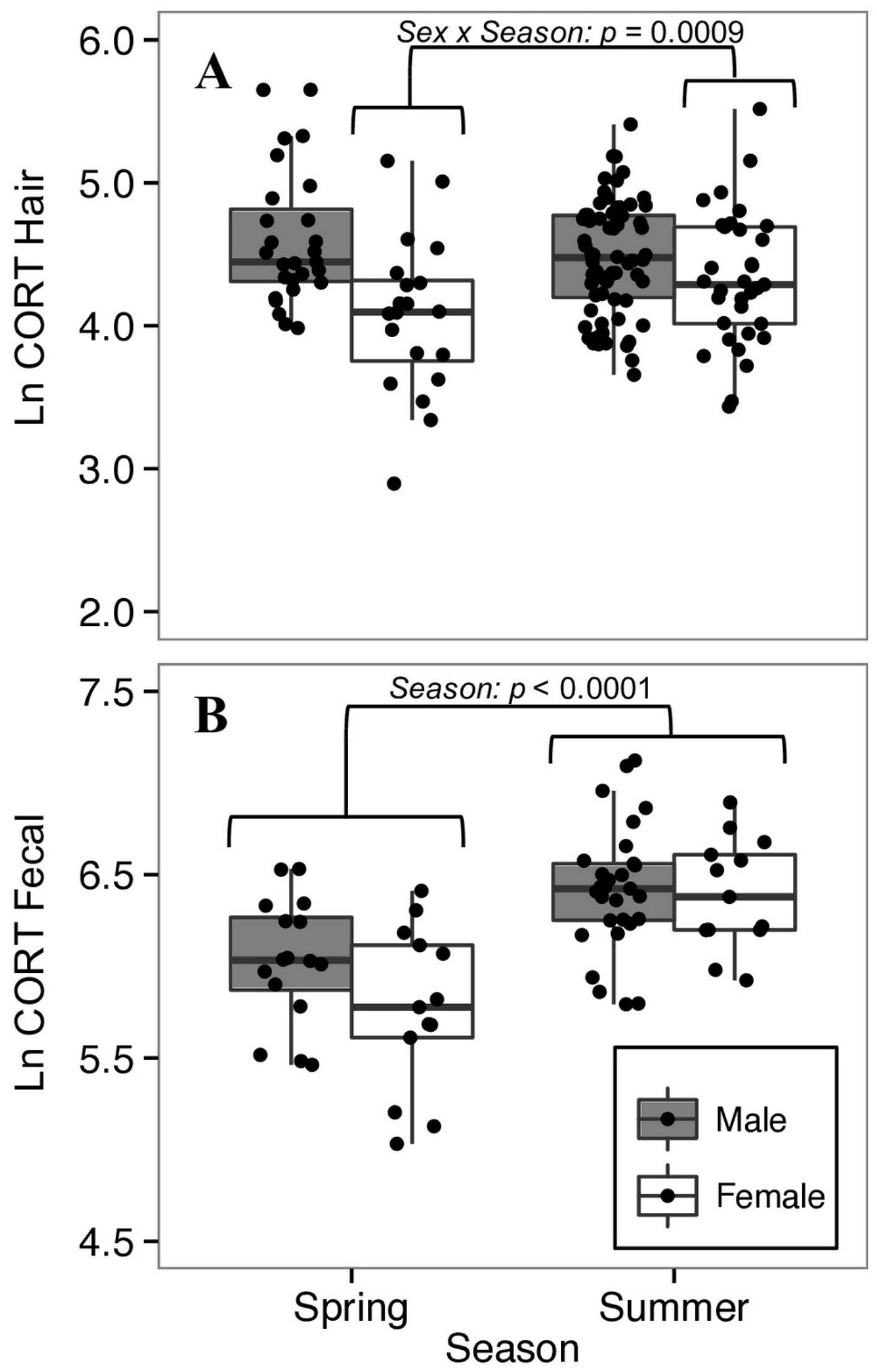
Figure 6

Correlation between hair corticosterone levels and fecal corticosterone metabolites for white-footed mice $(n=180)$ captured in the Thousand Islands National Park, Canada.

Both CORT measures were quantified in $\mathrm{ng} / \mathrm{g}$ and In-transformed.

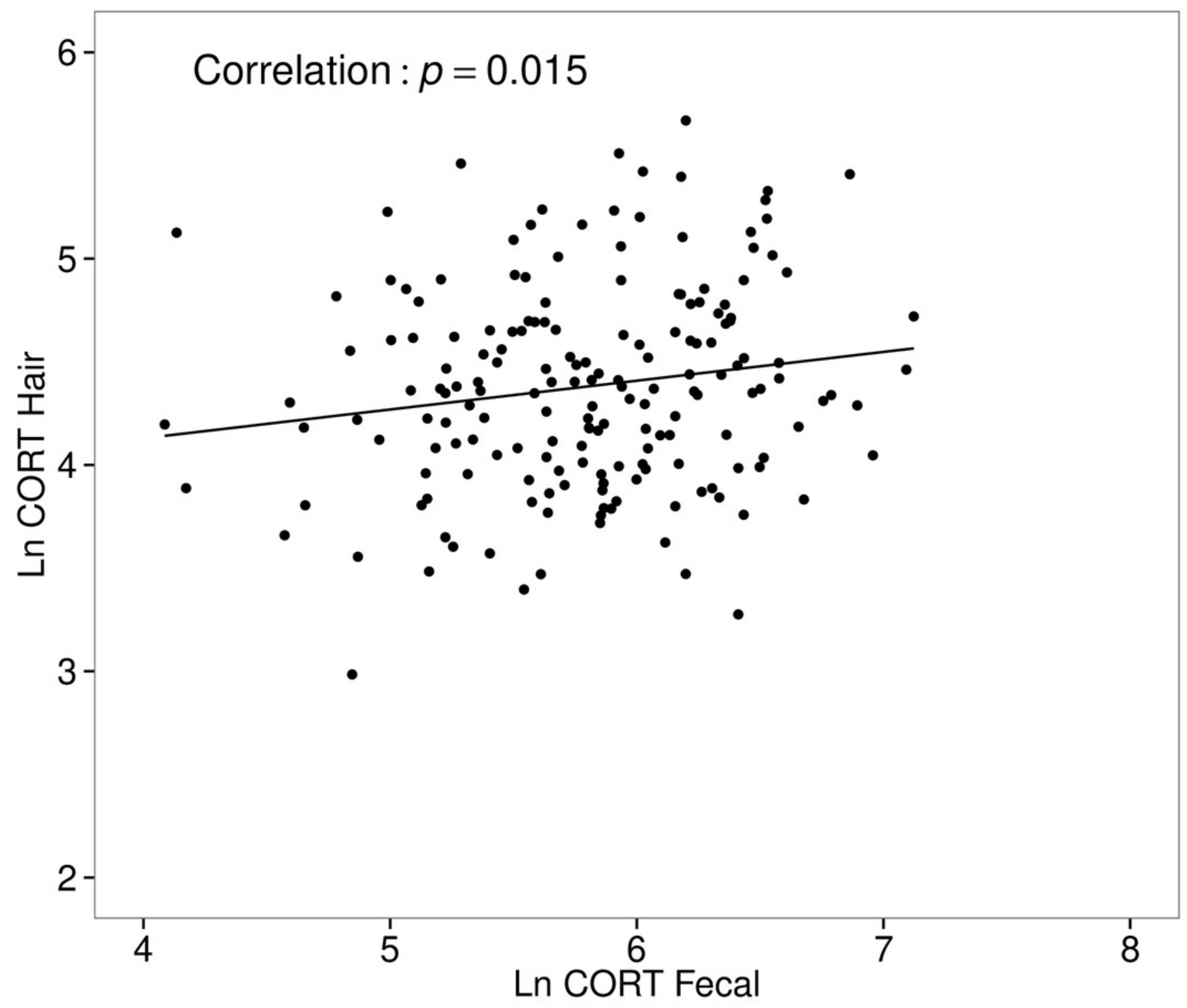

